\title{
The Atlantic Meridional Overturning Circulation and the subpolar gyre observed at the A25-OVIDE section in June 2002 and 2004
}

\author{
Pascale Lherminier ${ }^{\mathrm{a}}{ }^{\star}$, Herlé Mercier ${ }^{\mathrm{a}}$, Thierry Huck ${ }^{\mathrm{a}}$, Claire Gourcuff ${ }^{\mathrm{a}}$, Fiz F. Perez ${ }^{\mathrm{b}}$, Pascal Morin ${ }^{\mathrm{c}}$, \\ Artem Sarafanov $^{d}$ and Anastasia Falina ${ }^{d}$ \\ a Laboratoire de Physique des Océans, UMR6523, Ifremer, CNRS, IRD, UBO, Plouzané, France \\ ${ }^{\mathrm{b}}$ Instituto de Investigaciones Marinas (CSIC), Vigo, Spain \\ ${ }^{\mathrm{c}}$ Adaptation et Diversité en Milieu Marin, UMR7144, Station Biologique de Roscoff, CNRS, UPMC, \\ Roscoff, France \\ ${ }^{d}$ P.P. Shirshov Institute of Oceanology, Moscow, Russia
}

\author{
*: Corresponding author : Pascale Lherminier, Tel.: +33 2982 24362; fax: +33 2982 24496, email address : \\ pascale.lherminier@ifremer.fr
}

\begin{abstract}
:
The horizontal circulation of the subpolar gyre and the Meridional Overturning Circulation (MOC) are investigated here by comparing two snapshots of the North Atlantic as delivered by two hydrographic sections between Greenland and Portugal. The corresponding cruises were carried out in June-July 2002 and June-July 2004 on R/V Thalassa within the framework of the Ovide project. The absolute transports in June 2004 are described in detail, and then compared with transports in June 2002. The MOC (in density coordinates), driven by the volume balance between the northward North Atlantic Current (NAC) and the net southward export of dense water from the subpolar gyre, did not change: $\mathrm{MOC}_{\alpha}=16.3 \pm 2.4 \mathrm{~Sv}\left(1 \mathrm{~Sv}=10^{6} \mathrm{~m}^{3} \mathrm{~s}^{-1}\right)$. Its upper limb, above $\sigma_{1}=32.1$, is decomposed into two main branches, the Eastern NAC (ENAC) and the Western NAC (WNAC), that transport about 8 Sv each. In the lower limb of the MOC, we find a 4-5 Sv increase in the cyclonic circulation of the subpolar gyre between June 2002 and 2004, affecting mainly the intermediate water without changing the $\mathrm{MOC}_{\sigma}$ amplitude. Accordingly, the $14 \pm 2$ Sv transport over Reykjanes Ridge in June 2004 (between $58^{\circ} 50^{\prime} \mathrm{N}$ and Iceland) is estimated to have been $4-5$ Sv stronger than in June 2002. Sustaining this observation, a relatively warm and salty anomaly coming from the Iceland Basin was found in the East Greenland-Irminger Current (EGIC) in June 2004, along with a modified vertical structure of the transport that shows a 4-5 Sv intensification of the net southward flow in the corresponding layer. Overall, in June 2004, the EGIC (from the surface to $\sigma_{0}=27.8$ ) is found at 23.7 $\pm 1.4 \mathrm{~Sv}$ in June 2004, and the Deep Western Boundary Current (DWBC) below sums up to $11.2 \pm 1.7 \mathrm{~Sv}$, so that the western boundary current is $\sim 5 \mathrm{~Sv}$ stronger than in June 2002.
\end{abstract}

Keywords: North Atlantic; Subpolar gyre; Meridional Overturning Circulation; OVIDE; Hydrology; ADCP 


\section{Introduction}

Atmospheric modes of variability such as the North Atlantic Oscillation (NAO) are thought to be important drivers for the natural variability of the ocean circulation over decadal timescales. Combining several datasets, Curry and McCartney (2001) and Häkkinen and Rhines (2004) were able to construct indices that reflect the slowing down of the subpolar gyre after 1995. It is most likely related to the change of the NAO index averaged on the winter months, from persistent positive values in the beginning of the 1990s, to mostly neutral or negative values until 2006. Studies using hydrological data enlightened the variability of the position of the main fronts in the subpolar North Atlantic (Bersch et al., 1999; Flatau et al., 2003; Sarafanov et al., 2008; Häkkinen and Rhines, 2009): while the Subarctic Front was moving westward in the late 1990s, more water of subtropical origin could invade the Iceland Basin, changing the balance of heat and salt in the whole subpolar gyre (Hátún et al., 2005; Thierry et al., 2008; Sarafanov, 2009).

However, the mechanisms involved in the ocean response to forcing anomalies from weekly to decadal timescales are far from being accounted for in the oceanographic literature. In particular, only relatively few observations provide information on the large-scale absolute transports in the entire water column, useful to validate, or even constrain, numerical models needed to understand the dynamics. In this study, we interpret a snapshot of the North Atlantic circulation as measured across the OvideA25 section (Figure 1) in June 2004, and compare it to a similar analysis made for

\footnotetext{
${ }^{*}$ Corresponding author
}

June 2002.

The observed changes should be related to both the forced and internal variability of the circulation across the Ovide line in a period of neutral NAO. If two snapshots do not allow us to resolve the time scales associated with the observed variability, we will show, however that some of the features most likely participate to the contraction and salinification of the subpolar gyre observed since 1995 (Häkkinen and Rhines, 2004; Johnson and Gruber, 2007).

The method consists in the computation of absolute transports across the section via the inversion of the geostrophic velocity field combined with direct current measurements. The obtained transports show our best estimates of the circulation at the time of the surveys. This method is particularly suitable in the subpolar gyre where the circulation is strongly barotropic. The objective is to understand some aspects of the coupling between the subpolar gyre horizontal circulation and the Meridional Overturning Circulation (MOC).

As it was articulated by Schott and Brandt (2007),"estimating the variability of the MOC from the ocean observations alone is a challenging task". To begin with, one must define a suitable estimate of the overturning. In our study, the geographic dissociation of the warm northward inflow in the Western European Basin and the cold southward outflow in the Irminger Basin at the same depths (Figure 1) introduces a 3$4 \mathrm{~Sv}$ "Deacon-cell" effect $\left(1 \mathrm{~Sv}=10^{6} \mathrm{~m}^{3} \mathrm{~s}^{-1}\right)$ when the MOC is estimated by the transport integrated in depth coordinates (Schott and Brandt, 2007; Lherminier et al., 2007; Marsh et al., 2005). Computing the MOC in density coordinates $\left(\mathrm{MOC}_{\sigma}\right)$ takes into account the fact that most of the East Greenland-Irminger Current (EGIC) 

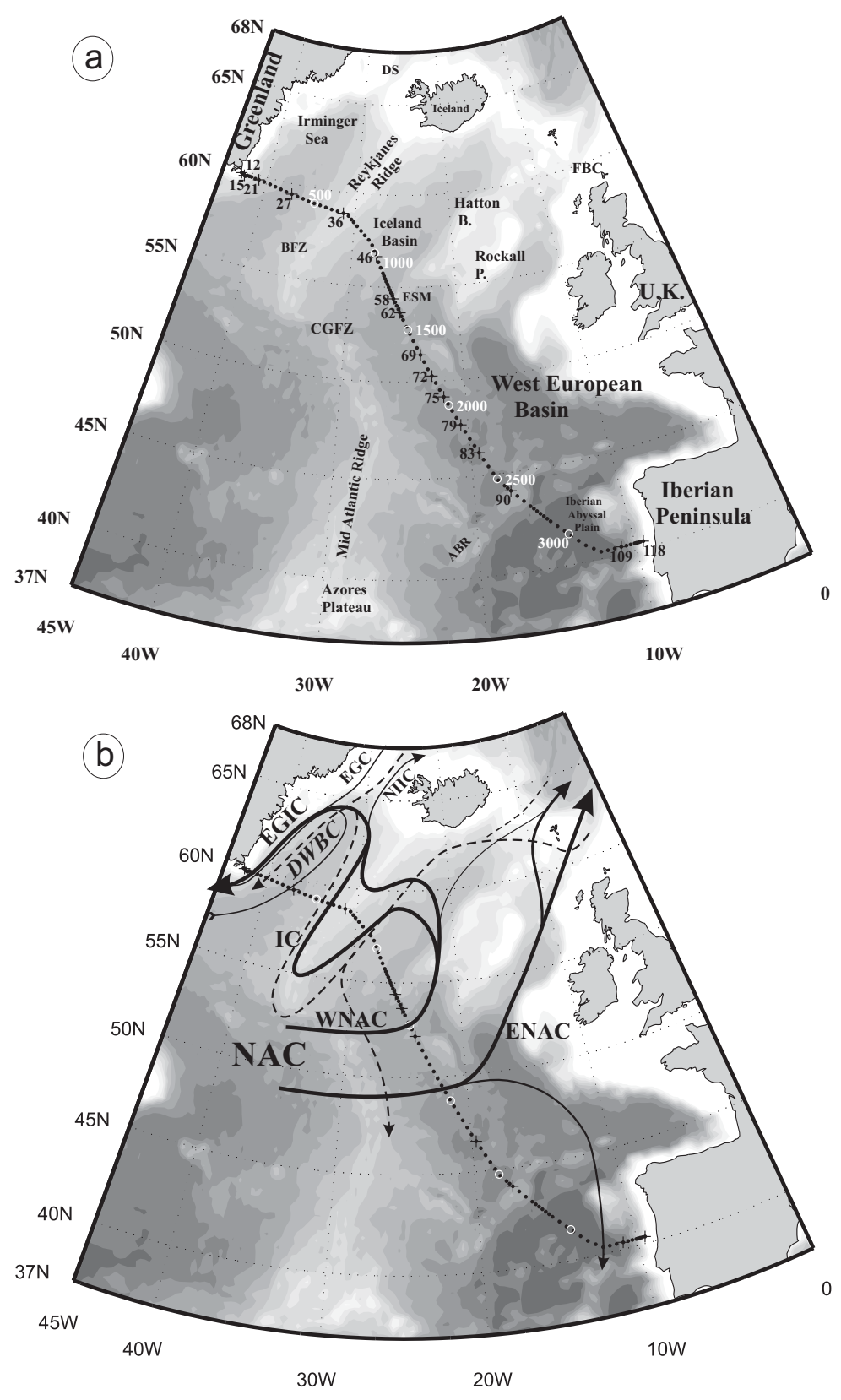

Figure 1: (a) Ovide hydrological stations (black numbers) plotted on bathymetry (500m intervals). CGFZ: Charlie-Gibbs Fracture Zone; BFZ: Bight Fracture Zone. FBC: Faroe-Bank Channel. ESM: Eriador Seamount; ABR: Azores-Biscay Rise. White numbers refer to the along-section distance from Greenland $\left(60^{\circ} \mathrm{N} 43^{\circ} 09^{\prime} \mathrm{W}\right)$. (b) A schematic view of the upper and deep-ocean currents (plain and dashed lines, respectively) following Schott et al. (2004), apart from a more upstream separation of the North Atlantic Current in an eastern (ENAC) and a western (WNAC) branch, as suggested by Ovide observations. DWBC: Deep Western Boundary Current; EGC: East Greenland Current; EGIC: East Greenland-Irminger Current; IC: Irminger Current; NIIC: North Iceland Irminger Current. 
at $60^{\circ} \mathrm{N}$ ultimately belongs to the lower limb of the MOC, while the North Atlantic Current (NAC) at the same depths belongs to the upper limb. Thus it appears to better reflect the water mass transformation north of the Ovide section and the associated heat transport.

In the following, we first present our method for estimating the transports across the section. Next, we show that the $\mathrm{MOC}_{\sigma}$ was $16.3 \mathrm{~Sv}$ both in June 2002 and 2004 and analyze how the horizontal circulation contributes to the overturning. Using flux estimates at the Greenland-Scotland sills, we find that the transport over Reykjanes Ridge nearly doubled in 2004, and then identify the important role of the circulation at the intermediate levels in this pattern. The water masses sampled on the section are then described at the light of the computed transports, with an emphasis on the origin of observed changes in the Irminger Current and in the East Greenland-Irminger Current. The results and their limitations are then discussed in the last section.

\section{Data and Method}

\subsection{CTD, Oxygen and Silicate Data}

The Ovide 2004 survey was carried out on the French $\mathrm{R} / \mathrm{V}$ Thalassa. The hydrological section line (Figure 1) is identical to the line of Ovide 2002 discussed in Lherminier et al. (2007) (L07 hereafter). Observations started on 13 June 2004 and ended on 3 July 2004. It is composed of 106 CTD stations, beginning $8 \mathrm{Nm}$ from Greenland at station 12, and finishing at station 118 on the Portuguese shelf. When $\mathrm{R} / \mathrm{V}$ Thalassa arrived at the tip of Greenland, part of the shelf was covered with ice, but the East Greenland Coastal Current could be observed, in contrast with the 2002 survey where we could only begin sampling at the shelf break, $21 \mathrm{Nm}$ from Greenland.

At each station, measurements of temperature, conductivity and pressure were obtained using a Neil Brown Mark III CTD probe. Dissolved oxygen was measured with an SBE-43. The rosette was equipped with 28 8-liter bottles. Seawater samples were analyzed on board to determine salinity and dissolved oxygen concentration - for calibration purposes - as well as nutrients, $\mathrm{pH}$ and alkalinity used for anthropogenic carbon inventories (Pérez et al., 2008). The $\mathrm{CTDO}_{2}$ measurement accuracies are better than 1 dbar for pressure, $0.002^{\circ} \mathrm{C}$ for temperature, 0.003 for salinity and $1 \mu \mathrm{mol} \mathrm{kg}{ }^{-1}$ for dissolved oxygen (Billant et al., 2006). The vertical sections of properties $\left(\theta, \mathrm{S}, \mathrm{O}_{2}\right)$ are shown in Figure 2.

Silicate (actually orthosilicic acid $\mathrm{Si}(\mathrm{OH}) 4)$ was measured from bottle samples using Fanning and Pilson (1973) method with an Auto Analyser II Bran and Luebbe (Figure 3). We obtain a precision better than $\pm 0.25 \mu \mathrm{mol} \mathrm{l^{-1 }}$, i.e. $0.10 \%$ of the full scale in the WOCE standard (Joyce, 1991).

\section{2. $S A D C P$ Data}

The velocity and direction of the oceanic currents were measured along the route by the two Shipboard Acoustic Doppler Current Profilers (SADCP): an RDI Narrow Band at $75 \mathrm{kHz}$ (NB75) and an RDI Broad Band at $150 \mathrm{kHz}$ (BB150). Raw data were processed as explained in L07. At stations, SADCP profiles could be compared with Lowered ADCP profiles processed by the LDEO-Visbeck software (Visbeck, 2002).

Between the stations, we corrected the NB75 alignment by $+0.22^{\circ}$ so that we find 

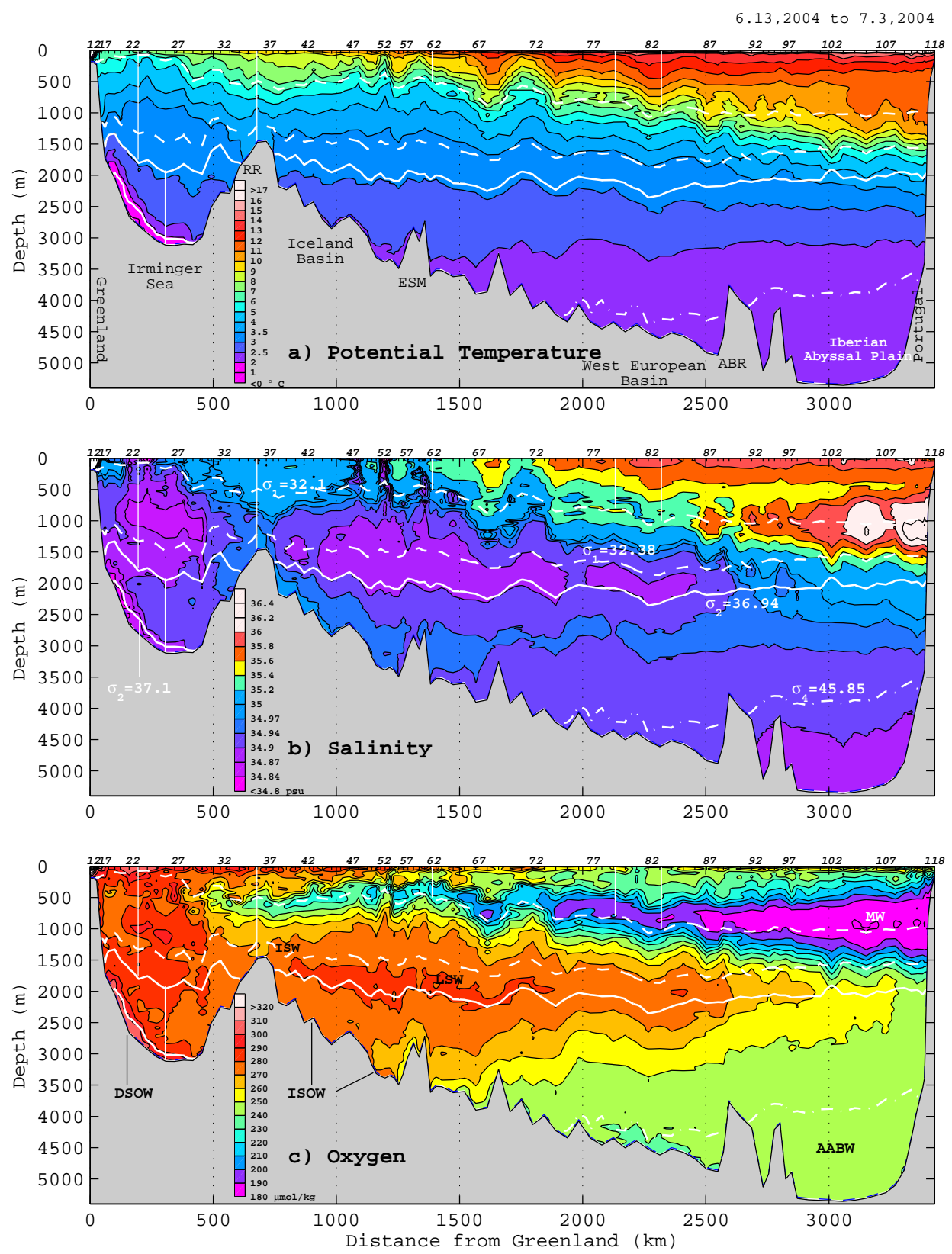

Figure 2: Ovide 2004 sections of (a) temperature, (b) salinity, (c) oxygen in distance-depth coordinates. Distance is calculated along the section from $60^{\circ} \mathrm{N} 43^{\circ} 09^{\prime} \mathrm{W}$ (see Figure 1 for distance). Isopycnals discussed in the text are plotted in white, with their values on (b). Station numbers and positions are indicated at the top of each subplot. Main geographical areas are indicated on (a). RR: Reykjanes Ridge; DSOW: Denmark Strait Overflow Water; ISOW: Iceland-Scotland Overflow Water; ISW: Icelandic Slope Water; LSW: Labrador Sea Water; MW: Mediterranean Water; AABW: Antarctic Bottom Water; see Figure 1 for the other abbreviations. The vertical white lines delimit from Greenland: the EGIC, the DWBC, the Reykjanes Ridge, the WNAC and the ENAC. 


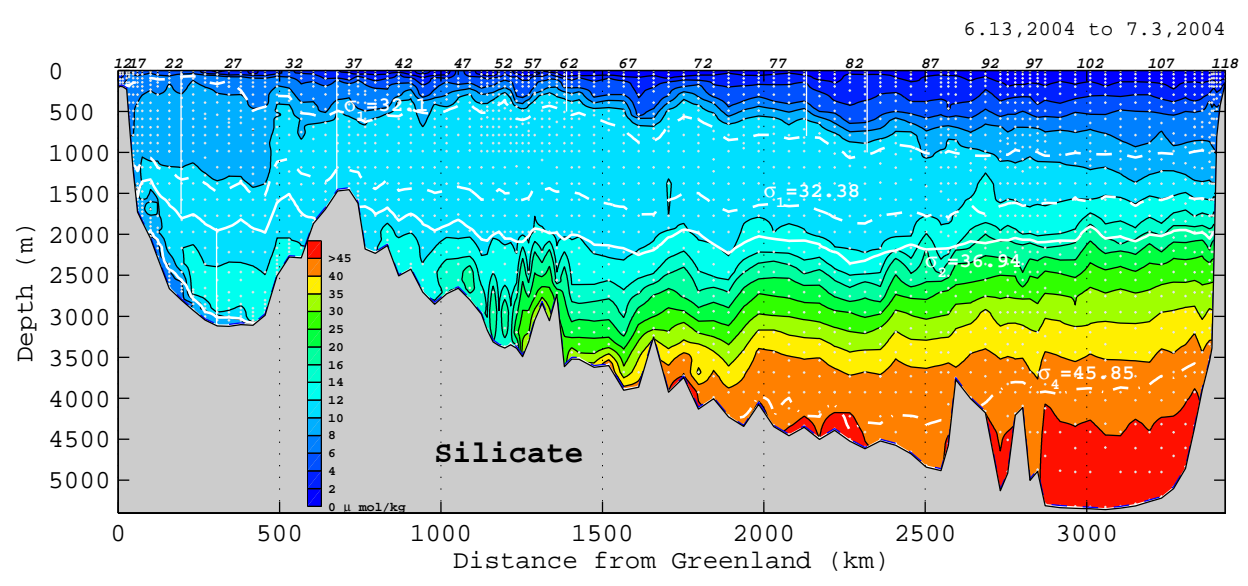

Figure 3: Ovide 2004 section of dissolved silicate $(\mathrm{Si}(\mathrm{OH}) 4)$, in $\mu \mathrm{mol} \mathrm{kg}{ }^{-1}$. Bottle levels are materialized with light grey dots. For each station, silicate profiles were interpolated with a $10 \mathrm{~m}$ vertical resolution using density from CTD data.

current velocity perpendicular to the ship track. This correction is different from the Ovide 2002 survey $\left(+0.45^{\circ}\right)$ in all likelihood because the placement of the GPS antennas was changed in the meantime, leading to a slight change in the ship mean heading estimates. In this work, we relied largely on the NB75 currents averaged in the layer from 200 to $400 \mathrm{~m}$ depth between stations. However, since this ADCP failed between stations 73 and 76, we used the BB150 data in the 40 to $130 \mathrm{~m}$ layer there, after making sure that the Ekman currents could be neglected (weak winds). The BB150 data were also more appropriate on the shallow East Greenland Shelf, from stations 12 to 15. An alignment correction of $-0.12^{\circ}$ was applied on the BB150 data.

Barotropic tidal currents were removed using the global 1/4 degree tide model of Egbert et al. (1994). Note that tidal currents that were removed were all smaller than the error estimate of the SADCP mean velocity between stations shown in Figure 4c.

\subsection{Transport Estimates Across the Sec- tion}

The data are combined in a generalized least squares inverse model (Lux et al., 2000), as in L07, to estimate the absolute velocity across the Ovide section and quantify the associated uncertainty based on one standard deviation (the standard error). We start from an a priori solution that consists of the geostrophic velocity field as the sum of the thermal wind and a priori (first guess) reference level velocities. The objective of the inversion is to refine the velocity estimates at the reference level by minimizing - in the least squares sense - a set of constraints given by independent estimates of transports (i.e. ADCP measurements and integral transports of mass and tracers) and the distance to the a priori solution. Each piece of information is weighted by an associated error (see L07 for more details). The model gives an absolute velocity field along with standard errors. All the transports discussed hereafter are counted positive northeastward and include the Ekman transport 

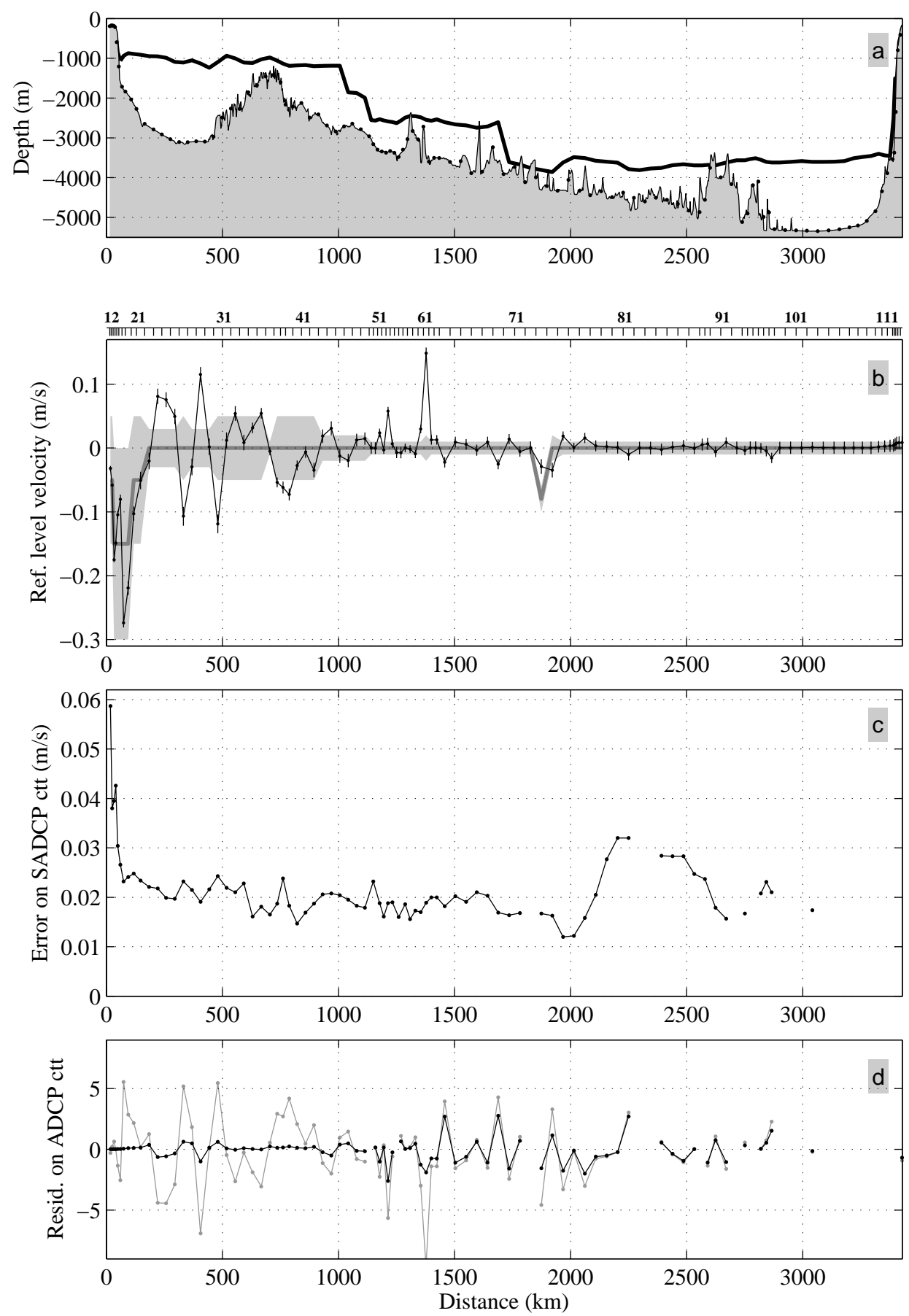

Figure 4: Inverse model set-up and performance for OV04. (a) Ovide section with a $2 \mathrm{~km}$ resolution bathymetry measured with a $12 \mathrm{kHz}$ sounder and the depth of the reference levels used in the inversion. (b) Velocities at the reference level: values after inversion (black dotted line) with final error interval, and $a$ priori values (grey line) and error (grey patch). (c) Error on the SADCP velocity used to constrain each pair of stations. (d) Residuals of the SADCP constraints before (dotted grey line) and after inversion (dotted black line) normalized by the SADCP errors shown above. 
and equally distributed in the first 30 meters. Sections 2.3.1 and 2.3.2 give the details of the constraints that are specific to the 2004 inversion. The reader not interested in those details might skip directly to the presentation of the resulting velocity field section 2.3.3.

\subsubsection{Selecting the a priori solution}

The reference level is set at different isopycnals depending on the region: $\sigma_{1}=$ 32.35 or bottom between stations 12 and $46, \sigma_{2}=36.94$ between stations 46 and 49, $\sigma_{2}=37$ between stations 49 and $70, \sigma_{4}=$ 45.84 or bottom between stations 70 and 118. The depth of the reference level is plotted in Figure 4a. In the western boundary current (stations 12 to 22), an a priori velocity value of $-0.15 \mathrm{~m} \mathrm{~s}^{-1}$ is chosen at the reference levels, based on the average of SADCP and Lowered ADCP (LADCP) observations of three different cruises (Fourex 1997 and Ovide). Otherwise, the a priori reference level velocity is set to 0 (stations 22-118) in agreement with the weak velocities measured by the LADCP, except at pair 62 (st. 73-74) where all current observations suggest a peculiar barotropic circulation (Figure 4b).

The a priori velocity error at the reference level, shown in grey in Figure $4 \mathrm{~b}$, is chosen between 0.01 and $0.15 \mathrm{~m} \mathrm{~s}^{-1}$ according to the observed variability of the circulation at this level. The large uncertainties, up to $0.15 \mathrm{~m} \mathrm{~s}^{-1}$, permitted in the Irminger-Iceland Basins, take into account the full-depth energetic features seen on the LADCP section (Figure 5a). Final estimates of the reference level velocities (Figure $4 \mathrm{~b}$ ) result from the final inversion called "OV04" in the following, and based on this a priori field plus all the constraints developed in section 2.3.2. Those velocities are found reasonably compatible with the first guess.

The a priori solution takes into account some specific patterns of the velocity field as measured by the LADCP in June 2004. Therefore, it is slightly different from the a priori solution that was chosen for the June 2002 section in L07. An experiment conducted with the same a priori solution as in 2002 showed that the adjustments made on the a priori velocity field improved the compatibility with the constraints developed hereafter, without changing the solution significantly.

\subsubsection{Constraints}

As in L07, the overall volume transport to the north is set to $1 \mathrm{~Sv}$, in agreement with the latest estimates of the Arctic exchanges with the North Atlantic (Cuny et al., 2005; Maslowski et al., 2004; Serreze et al., 2006). Imposing this constraint is also consistent with high resolution models, which show a monthly variability of $\pm 1 \mathrm{~Sv}$ across the Ovide section (A.-M. Treguier, pers. communication). Ganachaud (2003) shows that the ageostrophic variability of the ocean, induced by internal wave isopycnal heave has an uncompensated transport near the slopes, inducing a $3 \mathrm{~Sv}$ error in the volume constraint we set. The section was sampled within 20 days, so one might expect that this lack of synopticity has consequences on the net transport across the section, besides the effect of ageostrophic dynamics. However, typical mesoscale features are crossed within 1 or 2 days, i.e. much less than their typical timescale, so that eddies have actually a negligible net transport. For this reason, Ganachaud (2003) concluded that nonsynopticity is not the main issue in inverse analysis of hydrological surveys. As a result, the accumulated effect of non-synopticity, 

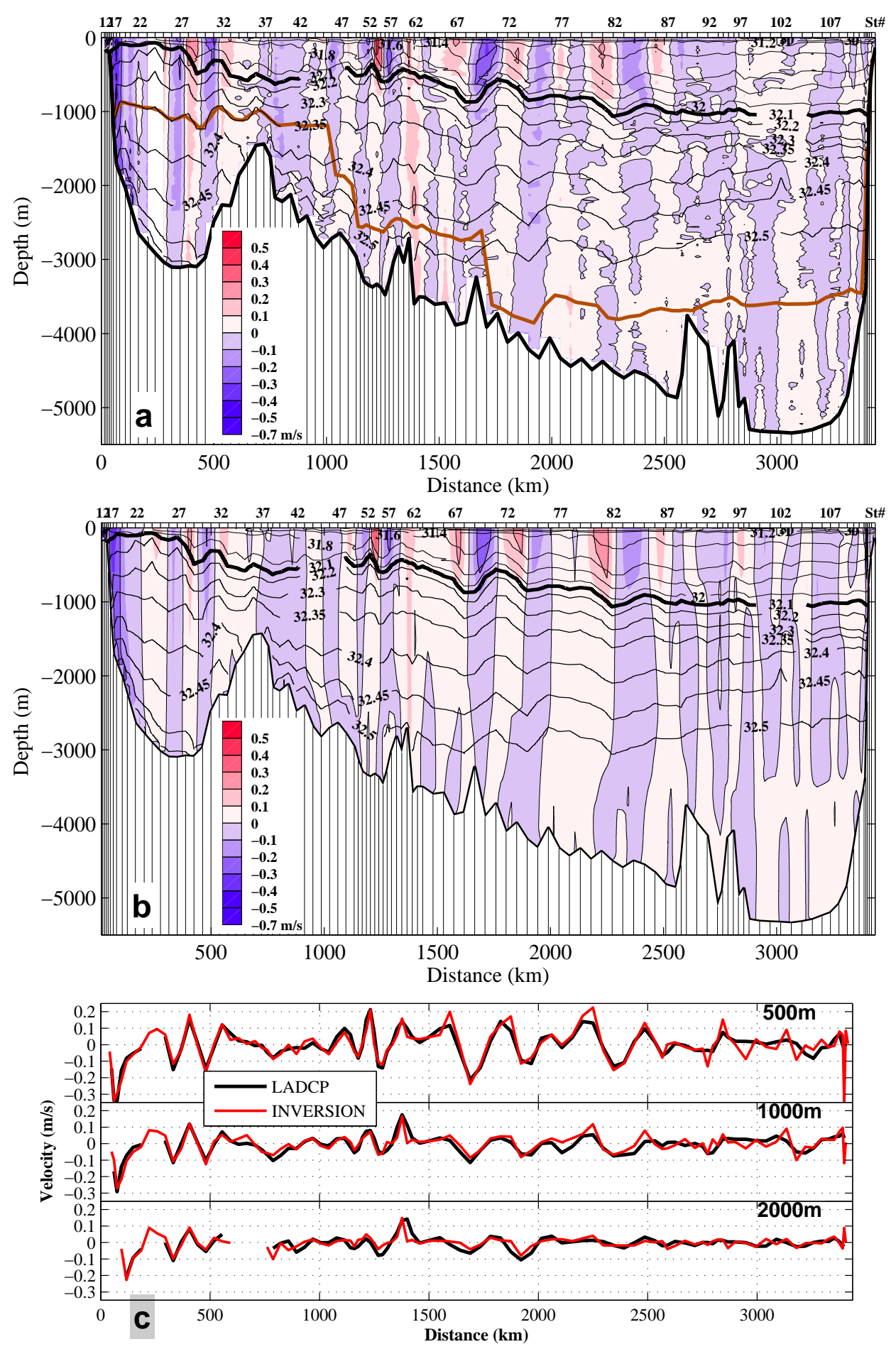

Figure 5: Ovide 2004 velocity section perpendicular to the section (a) measured with the LADCP at stations, (b) resulting from the geostrophic inversion, i.e. representative of the mean velocity between stations. LADCP and inverse velocity estimates are independent. Isopycnal $\sigma_{1}$ lines (black) and the reference levels (brown) are plotted. (c) Comparison of LADCP (black) and OV04 inversion (red) velocities at 500m, 1000m and $2000 \mathrm{~m}$ depths. LADCP data have been interpolated linearly at the mid-distance of station pairs. 
ageostrophy and monthly variability leads to a $\pm 3 \mathrm{~Sv}$ standard error on the volume transport. After the inversion OV04, a value of $-0.1 \pm 2.5 \mathrm{~Sv}$ is obtained (Table 1 ).

Other constraints are provided by the transports calculated from the SADCP measurements averaged between the stations and projected perpendicular to the section, to be directly comparable to geostrophic transports. Averaging SADCP data between stations below the Ekman layer minimizes the spatial aliasing and the impact of the ageostrophic dynamics. The errors on the SADCP velocity estimates are calculated as in L07 and lie between 0.01 and $0.06 \mathrm{~m} \mathrm{~s}^{-1}$ (Figure 4c), large values resulting from short-distance pairs or from bad weather. Unfortunately, the SADCP data could not be used in the oligotrophic Iberian Abyssal Plain, in all likelihood because suitable reflectors are much scarcer than in the other parts of the section. Residuals on SADCP constraints, normalized by the a priori error, are plotted Figure $4 \mathrm{~d}$. Comparing the a priori and the final residuals shows the sensible improvement in the compatibility between the geostrophic velocity field and the SADCP data.

The transport in the Eastern Boundary Current (stations 109-118) was estimated by LADCP measurements as in L07, and used as an additional constraint: $5 \pm 3 \mathrm{~Sv}$ in the top layer (down to $\sigma_{2}=36.94$ ), and $1 \pm 2 \mathrm{~Sv}$ below. It results in transports of $2.5 \pm 0.8 \mathrm{~Sv}$ and $1.5 \pm 0.8 \mathrm{~Sv}$ in those boxes after inversion. Adding all the ADCP constraints diminishes the uncertainties on the transport of each current (Table 1).

The solution minimizing the squared distance to the a priori solution and residuals of all the constraints above, shown in the "+ ADCP" column of Table 1, results in large uncertainties in the Iberian Abyssal Plain (IAP) deep circulation, as it could be expected from the lack of direct velocity measurements or ADCP constraints there. Furthermore, the net silicate transport of $67 \mathrm{kmol} \mathrm{s}^{-1}$ across the section is slightly high compared to what we can find in the literature (Fogelqvist et al., 2003; Álvarez et al., 2002; Dittmar and Kattner, 2003). To improve the silicate budget and reduce the uncertainties, we use an overall constraint of $0 \pm 30 \mathrm{kmol} \mathrm{s}^{-1}$. As expected, the silicate constraint reduces significantly the northward transport of Antarctic Bottom Water (AABW), but mainly in the IAP (Table 1) where no other data constrain the solution; the transport is hardly changed west of the Azores-Biscay Rise (Figure 1a) where the deep water is also rich in silicate. To compensate for this issue of the least squares method, we also constrain the bottom transport of the IAP to $0.8 \pm 0.8 \mathrm{~Sv}$, consistently with the method and estimates of McCartney (1992) and Saunders (1987). This way, we recover the $a$ priori geostrophic total transport of AABW with a more balanced impact of the silicate constraint east and west of the AzoresBiscay Rise, while the silicate transport is reduced to $5 \pm 28 \mathrm{kmol} \mathrm{s}^{-1}$. A detailed comparison between the solutions with or without the last 2 constraints shows that, considering the computed errors, both solutions are compatible (Table 1). However, we prefer to use the fully constrained solution, named "OV04", that both conserves silicate and is close to published estimates of the bottom water transport in the IAP (McCartney, 1992).

\subsubsection{Results}

The resulting OV04 velocity field is plotted in Figure 5b. The comparison with the 


\begin{tabular}{|l|c|c|c|c|c|}
\hline & $\begin{array}{c}\text { No } \\
\text { cstraint }\end{array}$ & $\begin{array}{c}\text { Volume } \\
\text { only }\end{array}$ & $\begin{array}{c}+ \\
\text { ADCPs }\end{array}$ & $\begin{array}{c}+ \\
\text { Silic. }\end{array}$ & $\begin{array}{c}+ \text { IAP } \\
\text { OV04 }\end{array}$ \\
\hline Net trsp. $(\mathrm{Sv})$ & $-25 \pm 26$ & $1.0 \pm 3.0$ & $0.8 \pm 2.9$ & $0.1 \pm 2.6$ & $\mathbf{- 0 . 1} \pm 2.5$ \\
\hline MOC $_{\sigma}(\mathrm{Sv})$ & & $16.4 \pm 3.4$ & $16.0 \pm 2.6$ & $16.3 \pm 2.5$ & $\mathbf{1 6 . 4} \pm 2.4$ \\
\hline Heat flux $\left(10^{15} \mathrm{~W}\right)$ & & $0.55 \pm 0.08$ & $0.53 \pm 0.07$ & $0.51 \pm 0.05$ & $\mathbf{0 . 5 1} \pm 0.05$ \\
\hline Sil. flux $\left.(\mathrm{kmol} \mathrm{s})^{-1}\right)$ & & $-104 \pm 160$ & $67 \pm 117$ & $4 \pm 29$ & $\mathbf{5} \pm 28$ \\
\hline EGIC, st.12-21 $(\mathrm{Sv})$ & $-18.8 \pm 7.4$ & $-11.5 \pm 6.9$ & $-23.8 \pm 1.4$ & $\mathbf{- 2 3 . 7 \pm 1 . 4}$ & $\mathbf{- 2 3 . 7} \pm 1.4$ \\
\hline DWBC, st.12-27 $(\mathrm{Sv})$ & $-11.8 \pm 5.4$ & $-8.2 \pm 4.4$ & $-11.6 \pm 1.8$ & $-11.3 \pm 1.7$ & $\mathbf{- 1 1 . 2} \pm 1.7$ \\
\hline AABW,WEB $(\mathrm{Sv})$ & $0.9 \pm 2.1$ & $1.2 \pm 2.0$ & $1.3 \pm 1.7$ & $0.7 \pm 1.0$ & $\mathbf{1 . 0} \pm 0.6$ \\
\hline AABW,IAP $(\mathrm{Sv})$ & $1.0 \pm 2.0$ & $1.2 \pm 1.9$ & $0.9 \pm 1.7$ & $0.3 \pm 1.3$ & $\mathbf{0 . 7} \pm 0.7$ \\
\hline
\end{tabular}

Table 1: Results of different inversions, beginning with no constraint except the reference velocity and associated errors ("No cstraint"), and progressively adding the different types of constraints. "Volume only" includes the $1 \pm 3 \mathrm{~Sv}$ overall transport. The "+ ADCPs" includes the volume constraint and the SADCP between Greenland and the Iberian Abyssal Plain (IAP) and the LADCP on the eastern boundary. "+ Silic." conserves also the silicate content north of the section, and "+ IAP" adds a constraint on part of the bottom transport (details in the text). The last column corresponds to the final solution. Note that for each inversion, all constraints are applied in once. The "Net trsp" is the total transport across the section after inversion; $\mathrm{MOC}_{\sigma}$ is the Meridional Overturning Circulation integrated in isopynal layers. The heat flux is computed as $\iint \rho C_{p} v \theta d x d z$ (where $C_{p}$ is the specific heat of water, $v$ its velocity and $\theta$ the potential temperature relative to $0^{\circ} \mathrm{C}$ ), neglecting the fact that the net transport is not exactly zero. The EGIC and the DWBC are separated by $\sigma_{2}=36.94$; the total transport below $\sigma_{4}=45.85$ in the Western European Basin (called AABW-WEB) is shown versus its contribution in the IAP (AABW-IAP, between stations 92 and 109). 
quasi-independent LADCP data Figure 5a and $5 \mathrm{c}$ is remarkable, considering that the LADCP velocity field is aliased by the discrete spatial sampling (see L07 for evidence of this aliasing). Indeed, all the main features are resolved in both velocity fields with similar intensities, although the inverse solution is a geostrophic average between stations and the LADCP profiles are local measurements.

In Figure 5c, comparisons at three selected depths above 2000m (LADCP data are more uncertain below) show that the agreement is not as good in the IAP, as a result from the lack of SADCP constraints there. However, no bias could be detected, and the mesoscale patterns seem to be simply smoothed out, as expected. North-west of the IAP, the standard deviation of difference between the inverse and LADCP velocities is similar to the LADCP precision, i.e. $\sim 0.03 \mathrm{~m} \mathrm{~s}^{-1}$.

\section{Analysis of the Meridional Over- turning Circulation and the Heat Flux}

\subsection{The Meridional Overturning Circula- tion}

The vertical structure of the circulation during Ovide 2004 (OV04 solution) is plotted in Figure 6, along with Fourex 1997 (in August 1997, called 4X97 hereafter) and Ovide 2002 (in June 2002, called OV02 hereafter) that were presented in L07. The transports integrated in density layers (thin lines) depict the transport of the two limbs of the $\mathrm{MOC}_{\sigma}$ : northward above $\sigma_{1} \sim 32.1$ and southward below. Once accumulated from the bottom with a change in the sign (thick lines), the value of the $\mathrm{MOC}_{\sigma}$ can be read as the maximum, i.e. $16.4 \mathrm{~Sv}$ in OV04, 16.2 Sv in OV02 and 18.5 Sv in 4X97,

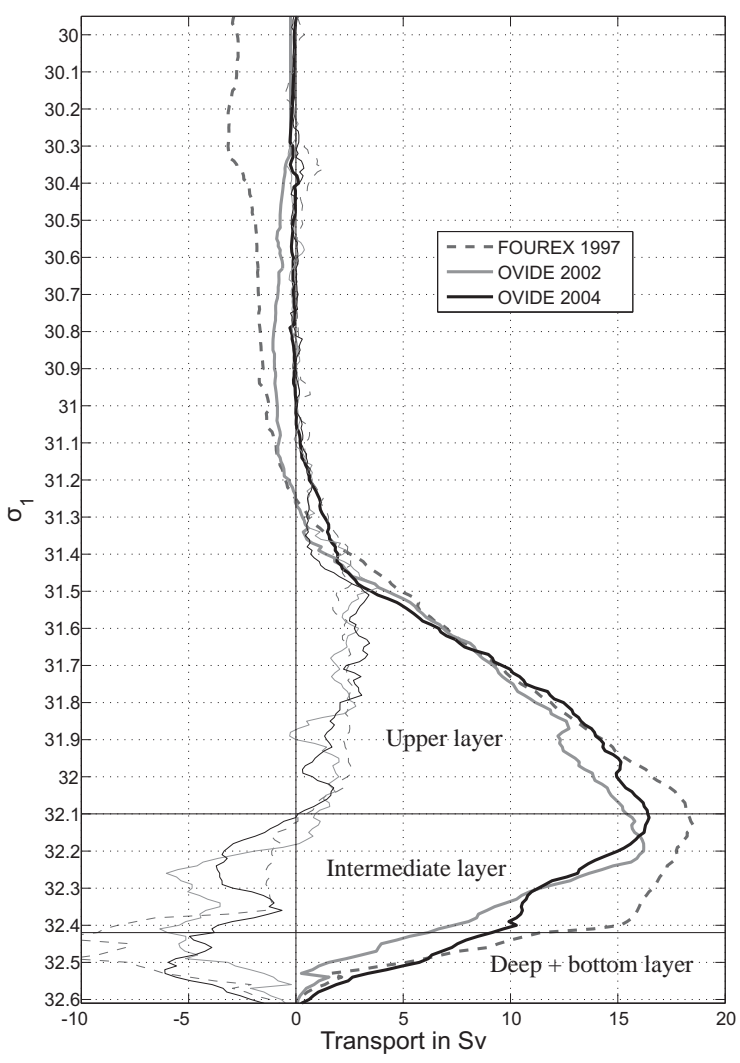

Figure 6: Transport integrated in density $\left(\sigma_{1}\right)$ layers with a $0.01 \mathrm{~kg} \mathrm{~m}^{-3}$ resolution (thin lines) across Ovide section in OV02 and OV04 (grey and black respectively) and across Fourex section in $4 \mathrm{X} 97$ (dashed grey). Values were multiplied by 10 for clarity. The same transports accumulated from the bottom are shown in thick lines. The sign was changed (positive north-eastward) so that the maximum corresponds to the $\mathrm{MOC}_{\sigma}$ values (see text). The line at $\sigma_{1}=32.42$ gives the limit of the deep water $\left(\sigma_{D}\right)$, and 32.1 the density of the $\mathrm{MOC}_{\sigma}$ maxi$\operatorname{mum}\left(\sigma_{M O C}\right)$. 
with an uncertainty of $\pm 2.4 \mathrm{~Sv}$ given by the inverse model. Unlike L07, we calculate the $\mathrm{MOC}_{\sigma}$ by accumulating the transport from the bottom, since we realized that the non-zero net transport is a consequence of the large scale circulation through the Arctic Ocean, and therefore affects mainly the lightest waters that pass the sills. This is the reason why the 1997 estimate is $0.5 \mathrm{~Sv}$ weaker than in L07. So we conclude that we obtain a similar MOC in June 2002 and June 2004, one that is weaker than in 1997. As in OV02, the $\mathrm{MOC}_{\sigma}$ amplitude is only marginally affected by the ADCP constraints (Table 1), and its estimation error is mainly related to the uncertainty on the net transport across the section.

In the following, the isopycnal of the maximum of the MOC will be labelled $\sigma_{M O C}$ (i.e. $\sigma_{1}=32.2$ in 2002 and 32.1 in 2004), and the layer above will be referred to as the upper layer. The isopycnal $\sigma_{D}$ between the intermediate and deep layers is set at $\sigma_{2}=36.94$, that corresponds to $\sigma_{1} \sim 32.42$ or more classically $\sigma_{0} \sim 27.8$. The isopycnal $\sigma_{B}$ separates the deep and the bottom layers that transport, respectively the North-East Atlantic Deep Water (NEADW) and the Denmark Strait Overflow Water (DSOW) in the Irminger Sea. This limit is set here at $\sigma_{0}=27.88$, i.e. $\sigma_{1} \sim 32.54$ or $\sigma_{2} \sim 37.1$.

The western boundary current, composed of the East-Greenland/Irminger Current (EGIC) and the Deep Western Boundary Current (DWBC), is an important contributor to the southward branch of the MOC. Near Greenland, we define the DWBC as the southward transport of water denser than $\sigma_{D}$ between the slope and the deepest station in the Irminger Sea (station 27 in 2004), following here the definition of Bacon (1998a). Its transport is estimated at $11.2 \pm 1.7 \mathrm{~Sv}$. It is $2 \mathrm{~Sv}$ stronger than in

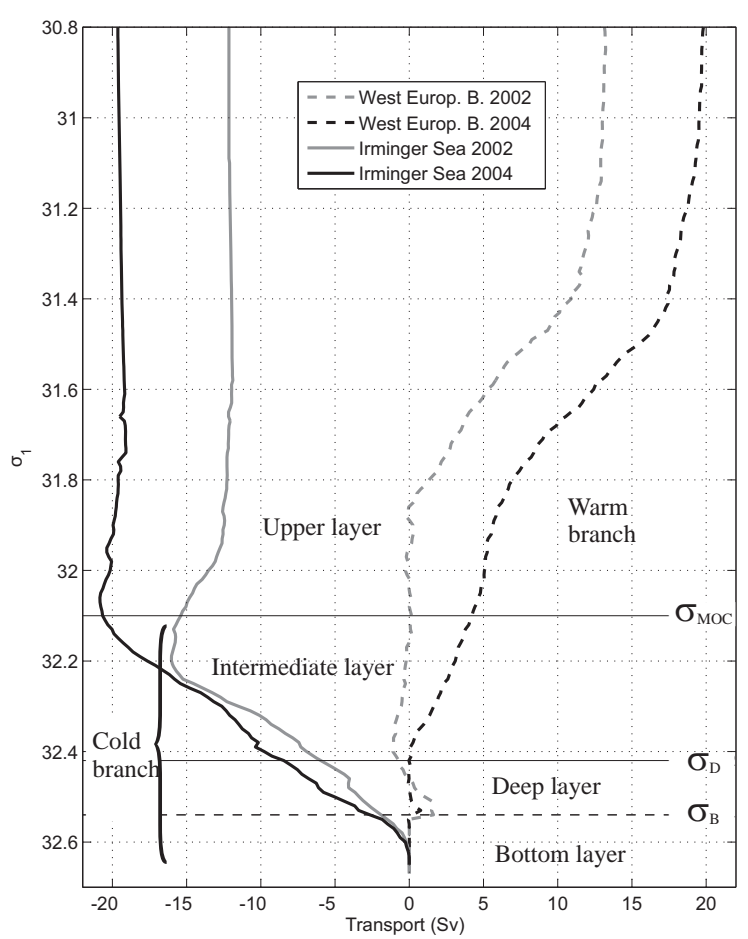

Figure 7: Transport in the Irminger Sea (plain lines) and in the West European Basin (dashed lines), accumulated from the bottom in 2002 (grey) and 2004 (black), as a function of $\sigma_{1} \cdot \sigma_{M O C}$ is the level of the $\mathrm{MOC}_{\sigma}$ maximum, $\sigma_{D}$ is the upper limit of the deep water, and $\sigma_{B}\left(\sigma_{1}=32.54\right)$ the upper limit of the DSOW layer. 
OV02, and similar to the 4X97 value (L07). In terms of decadal variability, the DWBC was found to increase by at least $2 \mathrm{~Sv}$ between the mid-1990s and the 2000s around a mean value of $\sim 9 \mathrm{~Sv}$ (Sarafanov et al., 2009, 2010a), close to our 2002 estimate. Mooring arrays at Cape Farewell gave $7.8 \mathrm{~Sv}$ in 2005-2006 (Bacon and Saunders, 2010) and $13 \mathrm{~Sv}$ in 1978 (Dickson and Brown, 1994). So the DWBC measured in 2004 stands in the upper range of the different estimates.

The EGIC, above the DWBC, also contributes to the southward transport of dense water below the density of the MOC maximum $\left(\sigma_{M O C}\right)$. This dense part of the EGIC $\left(\sigma_{1} \geq \sigma_{M O C}\right)$ transports $24.2 \pm 2.0 \mathrm{~Sv}$ in OV04 (stations 12-23), $6 \mathrm{~Sv}$ more than in OV02, when the EGIC is defined here from the Greenland to the pair of stations where the flow reverses to the north (at $59^{\circ} 41^{\prime}$ $39^{\circ} 35^{\prime}$ both years, i.e. $200 \mathrm{~km}$ from Greenland). However, part of this change is due to an intensified cyclonic circulation in the Irminger Sea, and once integrated on the basin (Figure 7), the net increase is only $3 \mathrm{~Sv}$ in the EGIC. So the transport of the dense part of the western boundary current (the DWBC plus the EGIC contributing to the MOC) is about $5 \mathrm{~Sv}$ larger in June 2004 than in June 2002, although the net $\mathrm{MOC}_{\sigma}$ is the same. As the Reykjanes Ridge acts as a natural barrier in the deep horizontal circulation, the total baroclinic transport shown in Figure 6 has been decomposed west and east of the ridge in Figure 7 . The baroclinic structure of the upper layer (Figure 7 , is similar for both inversions, showing mainly the northward transport of the lightest waters of the North Atlantic Current in the Western European Basin. However, the layer below behaves differently: no net transport is found east of the ridge in OV02, but in OV04, approximately $5 \mathrm{~Sv}$ of intermediate waters flow to the north into the Western European Basin, while a similar additional flow is found southwards in the Irminger Sea above the DSOW, between $\sigma_{M O C}$ and $\sigma_{B}$. In this export, the contribution of the upper intermediate layer $\left(\sigma_{M O C}<\sigma_{1}<32.25\right)$ is particularly strong in 2004. Those changes will be further discussed in the last section.

\subsection{The heat flux}

In OV04, the net heat transport northward amounts to $0.51 \pm 0.05$ PW $\left(1 \mathrm{PW}=10^{15} \mathrm{~W}\right)$; it was found at $0.44 \mathrm{PW}$ in OV02 and 0.66 PW in 4X97, with a similar error (L07). So the net heat flux is slightly, but not significantly, higher in OV04 than in OV02. A small part of the difference $(0.007 \mathrm{PW})$ is due to a $1.6^{\circ} \mathrm{C}$ warmer surface layer (over 40 meters), due to a particularly warm Spring in 2004.

In June 2002 and 2004, the net heat fluxes are significantly smaller than in August 1997, with Ovide values closer to the climatological heat flux (Álvarez et al., 2002). Only 0.02 PW could be explained by the slightly different locations of the sections (see Fig. 1 and the discussion in L07). Although we cannot prove it yet, we expect some correlation between the heat flux and the $\mathrm{MOC}_{\sigma}$, since the area covered by the upper limb of the $\mathrm{MOC}_{\sigma}$ overlaps with the NAC that brings heat northward, and since the contribution of the eddies and meanders to the heat transport across the section was shown to be small (Treguier et al., 2006). Indeed, from ocean models constrained by observations, Huck et al. (2008) show a strong relation between $\mathrm{MOC}_{\sigma}$ (THC of their Figure 2) and heat flux at $48^{\circ} \mathrm{N}$, and both reached a maximum in the mid 1990's and have been declining since (T. Huck, personal communication). In contrast, one 
expects a weaker correlation between the MOC integrated over depth and the heat transport for sections crossing the subpolar gyre (Biastoch et al., 2007).

In the following section, we decompose the structure of the upper limb of the $\mathrm{MOC}_{\sigma}$ and show the similarities in June 2002 and 2004 despite a strong mesoscale turbulence. Then, we investigate the large scale horizontal circulation at intermediate depth, quantify its intensification in June 2004, and examine the consequences for the transport and hydrological properties of individual currents.

\section{Variability of the upper ocean cir- culation and its contribution to the MOC}

We propose now to identify the water masses and quantify the transports that contributes to the upper limb of the $\mathrm{MOC}_{\sigma}$, i.e. above $\sigma_{M O C}$ (Figure 8). East of Eriador Seamount, the transport is dominated by the large NAC sustained by the contrast between the relatively cold-fresh waters of the subpolar gyre and the warmersaltier water of subtropical origin (Belkin and Levitus, 1996; Bersch et al., 1999). In this front, the top layer salinity increases from about 35 to 35.6 (Figure 8a). Holliday et al. (2008) specify that over the 19762006 time period, the salinity values over the North-East Atlantic reach a maximum around 2004. The net northward flow of the NAC is scattered among powerful eddies and meanders within the front (Figure 8b).

\subsection{Westward shift of the NAC northwest- ern branch}

The northern limit of the NAC is observed in June 2004 at $53^{\circ} \mathrm{N}$ and $25^{\circ} \mathrm{W}$, near Eriador Seamount (the prolongation of
Hatton Bank, $1450 \mathrm{~km}$ from Greenland on the section). This current is found about $200 \mathrm{~km}$ to the south-east in June 2002, in the prolongation of the Rockall Plateau. At $52^{\circ} \mathrm{N}$, near the Charlie-Gibbs Fracture Zone (CGFZ), the position of the NAC is relatively constrained by the bathymetry. At Ovide latitudes, it is more spread out and Belkin and Levitus (1996) for example have reported shifts of the NAC position up to $300 \mathrm{~km}$ over a few months. However, the northern limit of the NAC is easily identified in Figure 8a and 8b, and seems to be influenced by the two topographic features south of the Rockall Plateau (Figure 8c). Its relatively southern position observed in June 2002 , near $51^{\circ} 30^{\prime} \mathrm{N}$, is possibly linked to the "southern mode" described by Bower and von Appen (2008): in 2002-2003, altimetry and float measurements show that the North Atlantic Current crossed the MidAtlantic Ridge at an extreme southern position, with a flow close to zero in the CGFZ. In June 2004, the flow through CGFZ is dominant again, and the NAC northern limit is found more to the north downstream during Ovide; large meanders also appears within the $1000 \mathrm{~km}$-wide NAC, in agreement with intense and sustained EKE observed by Häkkinen and Rhines (2009) in 2004. The velocity profile just north of the front is very barotropic, with a velocity of +0.15 $\mathrm{m} \mathrm{s}^{-1}$ at the reference level after inversion (Figure 4b, station 61), and recalls the observation of the NAC front made by Schott et al. (1999) at the CGFZ in 1997.

\subsection{Recirculation into the subtropical gyre}

The southern limit of the NAC is more difficult to determine, because it depends on how one takes into account the southward recirculation in the Iberian Basin. For convenience, we place the limit on the Azores- 

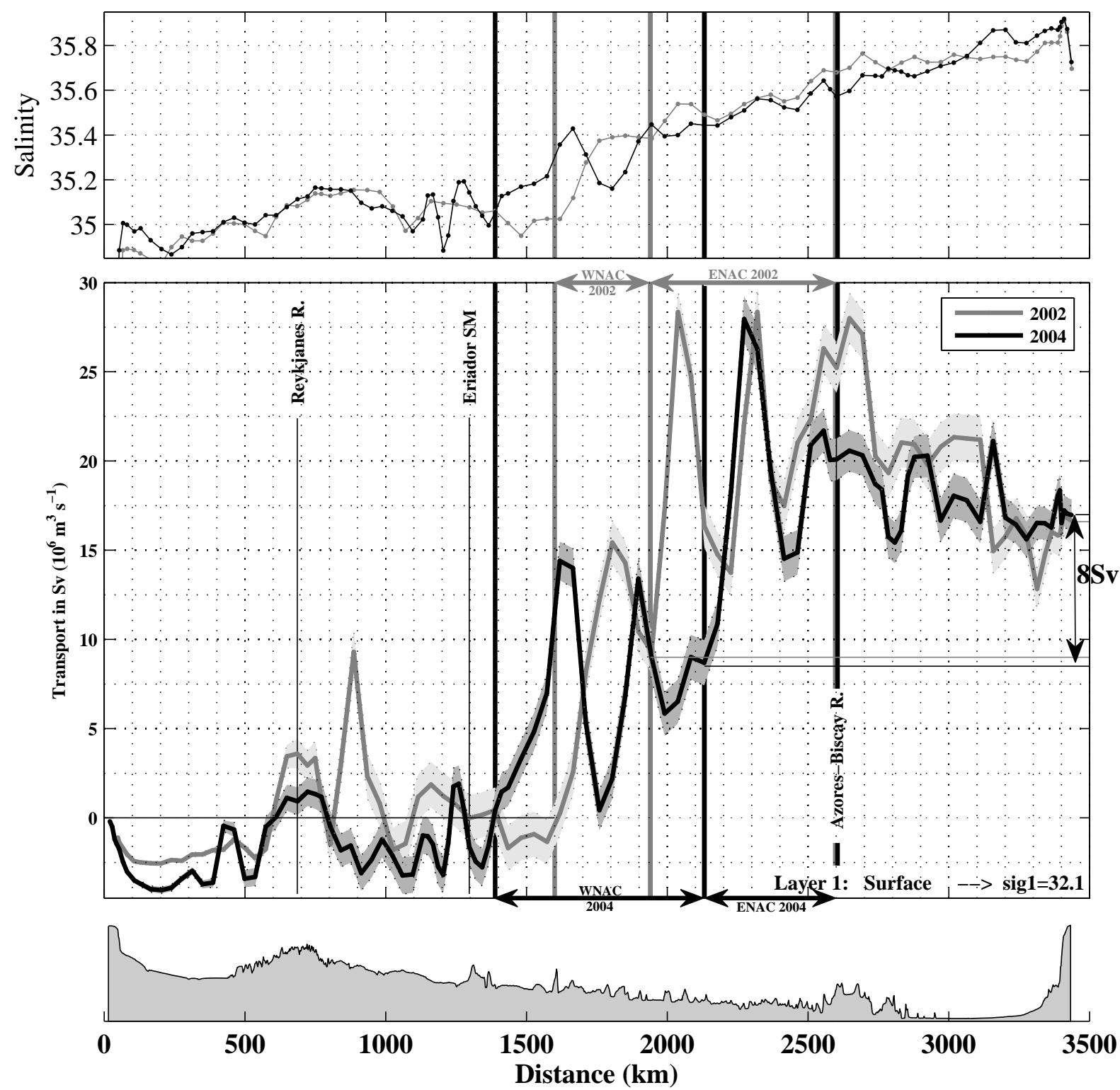

Figure 8: Properties of the upper layer (down to $\sigma_{M O C}$ ) in OV02 (grey) and OV04 (black). Top (a): mean salinity; middle (b): geostrophic absolute transports accumulated from Greenland to Portugal, positive north-eastward. Shaded areas indicate the error from the inversion for the cumulative transports. The reader might refer to Figure 1 for a schematic of the main current intersected by the Ovide line. The North Atlantic Current (NAC, stations 62 to 83 in Ovide 2004, and 49 to 64 in Ovide 2002) is composed of the WNAC and the ENAC, defined according to the text (separation at station 79 in Ovide 2004, and 56 in Ovide 2002). The distance is computed along the section from $60^{\circ} \mathrm{N}$ and $43^{\circ} \mathrm{W} 09^{\prime}$ (Greenland). Bottom (c): high-resolution bathymetry. 
Biscay Rise that, in the mean circulation scheme of Paillet and Mercier (1997), separates the broad northward flow associated with the NAC and the southward recirculation in the Iberian Basin. The transport of this southward recirculation amounts to $8 \mathrm{~Sv}$ in OV02 and $3 \mathrm{~Sv}$ in OV04 in the top layer (Figure 8), and was shown to be anticorrelated with the NAC northward transport in an eddy-resolving model (Treguier et al., 2006). So the southeastern part of the section mainly describes a varying anticyclonic circulation centered on the AzoresBiscay Rise, that is fed by the eastern part of the NAC and belongs to subtropical gyre.

\subsection{Branches and fate of the $N A C$}

Within the NAC, it is possible to distinguish several branches characterized by the maxima in the northward transport. Could our transport calculation be used to support the scheme in Figure 1b whereby the eastern part of the NAC (the ENAC) is mainly responsible for the flow at the Greenland-Scotland sills, and the western NAC (WNAC) is the main contributor to the flow over Reykjanes Ridge? The $16 \mathrm{~Sv}$ net transport of Atlantic water that feeds the Nordic seas and the North Atlantic subpolar gyre are found above $\sigma_{M O C}$, with no significant net transport below. This observation is consistent with the results of Bower et al. (2002), where most of the water crossing the Iceland-Faroes ridge to the north is lighter than $\sigma_{\theta}=27.5$ (i.e. above $\left.\sigma_{M O C}\right)$. Østerhus et al. (2005) estimate that $\sim 8 \mathrm{~Sv}$ flows through the Iceland-Scotland sills. In Figure 8 , accumulating $8 \mathrm{~Sv}$ of northward transport from Portugal westward along the section provides a possible means for defining the northern limit of the ENAC, with this contingent upon the hypothesis of no diapycnal flux and continuity of the streamlines. This way, the anticyclonic circulation that belongs to the subtropical gyre cancels. Due to the presence of meanders, different points fulfill this transport criterion, but there is one that seems more appropriate (vertical lines around $2000 \mathrm{~km}$ on Figure 8), as it marks the northwestern limit of a thermohaline front, with a salinity gradient of $0.15\left(1^{\circ} \mathrm{C}\right.$ in temperature). Between this separation point and Eriador Seamount lies a 0.4 salinity gradient that sustains the $8 \mathrm{~Sv}$ WNAC.

Using this criterion, the salinity range of the ENAC (35.4-35.6) is consistent with the 35.3-35.5 salinity range of the North Atlantic Water as reported by Holliday et al. (2008) in the salinity cores east and west of the Faroe Islands (the Faroe-Shetland Channel and the Faroe Current, respectively) in the early 2000s. By contrast, the fresher WNAC (35-35.4) is likely to be a minor source of the Nordic seas inflow, given the along-path freshening of the waters carried by the NAC from the Ovide section to the Iceland-Scotland sills.

Thus despite the fact that many of the features described here are transient, it is possible in OV02 and OV04 to separate schematically the $\mathrm{NAC}$ in two main branches corresponding to two distinct thermohaline fronts: the ENAC, mainly feeding the Nordic seas $(8 \mathrm{~Sv}$ ) plus the varying contribution to the subtropical gyre, and the WNAC, belonging to the Atlantic subpolar gyre. It is not clear yet whether this branching is characteristic of the surface circulation in the northern North Atlantic after the 2001 shift (Häkkinen and Rhines, 2009).

The upper part of the water transported from the West European Basin into the Irminger Sea by the WNAC looses buoyancy in winter, forming a water denser than $\sigma_{M O C}$ (Brambilla et al., 2008) that is ex- 
ported from the northeastern subpolar gyre via the Irminger Current.

\section{Variability of the transport over Reykjanes Ridge}

\subsection{The four boxes}

In order to determine our best estimate of the transport over Reykjanes Ridge in June 2002 and 2004, the volume between the Ovide section and the Greenland-Scotland sills can be divided into four boxes: east and west of Reykjanes Ridge, and above and below $\sigma_{D}$ (i.e. $\sigma_{2}=36.94$, Figure 9). This isopycnal is chosen because it traditionally defines the upper bound of the deep waters. In the following, we will consider that the whole product of the overflows belongs to the deep layer only. Indeed, south of $60^{\circ} \mathrm{N}$, the lighter form of those overflows is found in the North East Atlantic Deep Water (NEADW) formed in the Iceland Basin by the entrainment of Lower Deep Water (rich in AABW, see van Aken (2000) ) in the Iceland-Scotland Overflow Water (ISOW, itself the product of a mixing down the Iceland-Scotland sills as explained in Yashayaev and Dickson (2008); Sarafanov et al. (2010b)). The NEADW totally belongs to the lower layer, as attested by the increase in silicate concentration with depth, which exceeds $12 \mu \mathrm{mol} \mathrm{\textrm {kg } ^ { - 1 }}$ only below $\sigma_{D}$ on each side of Reykjanes Ridge in Figure 3. The Ovide section crosses Reykjanes Ridge at the latitude of $58^{\circ} 50^{\prime} \mathrm{N}$. As seen in Figure 2, the deep water lies below the top of Reykjanes Ridge. Considering that there is no sill in the ridge between the Ovide section and Iceland nor any evidence that the isopycnals rise northwards, significant quantities of deep water cannot pass over Reykjanes Ridge between the section and Iceland. Thus one finds three in- terfaces between those four boxes, and four interfaces with the subpolar seas.

We are interested in estimating the fluxes and errors through the seven interfaces of the four boxes, the transports across the Ovide line being known as a result of the previous inversions. The seven fluxes are linked with five equations: the balance of overall volume flux across the GreenlandScotland sills and the Ovide section (reflecting the overall volume conservation), and the volume conservation in the 4 boxes. The method and hypothesis used to estimate those fluxes are further described in the Appendix A. Note that the transport through the English Channel $(0.1 \mathrm{~Sv})$ is neglected.

\subsection{Transport estimates in June 2002 and 2004}

Transports estimated in OV02 and OV04 are illustrated in Figure 9. The variability of the transport above Reykjanes Ridge stands out. Increasing from 9.6 Sv in June 2002 to $13.8 \mathrm{~Sv}$ in June 2004, it quantifies the statement made in section 3.1: the subpolar gyre was found more energetic in June 2004. The additional 4-5 Sv found above the ridge in 2004 are consistent with a similar increase identified in the intermediate layer on both sides of the ridge (Figure 7).

One may object that the flow connecting the Iceland Basin and the Irminger Sea could have simply passed round the ridge more to the south in 2002 instead of over the ridge. However, the northward Irminger Current (Figure 1), as measured across the Ovide section west of the Reykjanes Ridge, did not vary significantly between OV02 and OV04 (Figure 8, between 530 and $700 \mathrm{~km}$ ); examining the barotropic transport, it was found at about $13 \mathrm{~Sv}$ from surface to bottom both years. It means that an additional westward flux appeared in the 

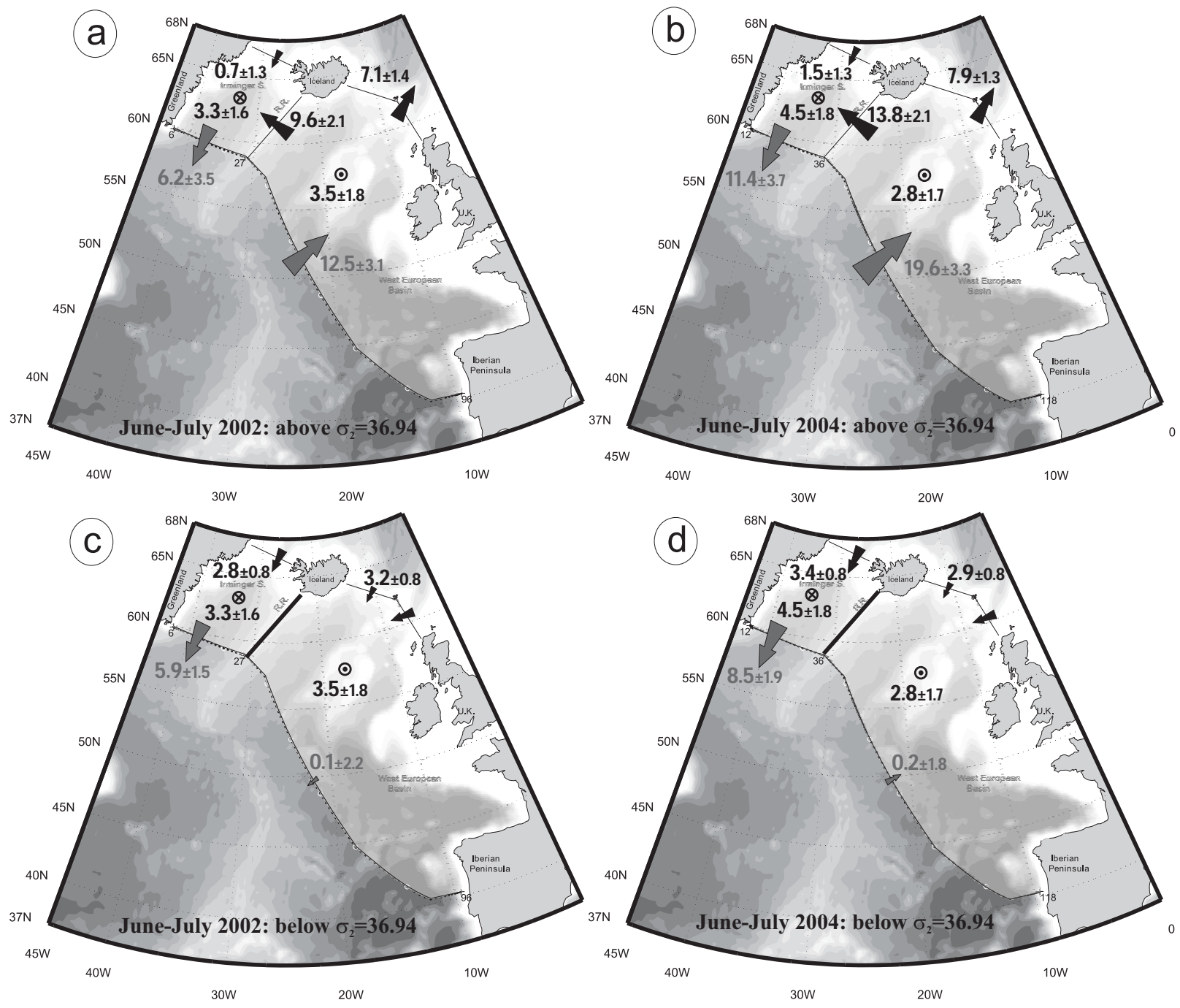

Figure 9: Transport balance between the Greenland-Scotland sills and the Ovide section (numbers in Sv) on top of the bathymetry. Top (bottom) plots refers to the layer above (below) $\sigma_{D}\left(\sigma_{0} \sim 27.8\right)$. OV02 results are on the left $(\mathrm{a}, \mathrm{c})$, OV04 on the right $(\mathrm{b}, \mathrm{d})$. Arrows indicate the direction, but their size are only a qualitative indication of the transports. Crosses and circles are for downward and upward net transports, respectively. Across the Ovide section, grey arrows and numbers come from the inversions described in Section 2.3. Black arrows and numbers come from the generalized least squares inversion discussed in Section 5 . 
intermediate layer above the ridge, that entirely fed a stronger export of water from the Irminger Sea.

The Denmark Strait overflow at Denmark Strait and the entrainment from the intermediate water tends also to be stronger in OV04 than in OV02, feeding the stronger Deep Western Boundary Current across Ovide. The overall picture is consistent with the relation between the overflow intensity and the subsequent entrainment, as shown in Price and Baringer (1994). However, the entrainment here is an estimate over the whole Irminger Sea, and some entrainment can be suspected within the Irminger Current, independently from the plume dynamics of the overflow (Lauderdale et al., 2008). Since the transport in the bottom layer at $60^{\circ} \mathrm{N}$ is similar in OV02 and OV04 (2 Sv, Figure 7), it is actually plausible that the overflow did not change much. No significant change can indeed be seen between May 2002 and 2004 in the transport of the bottom layer when looking at the $63^{\circ} \mathrm{N}$ Angmassalik timeseries reported by Dickson et al. (2008a) (considering advection times of about one month).

East of Reykjanes Ridge, the neutral transport of water denser than $\sigma_{D}$ through the Ovide section reflects the balance between the northward flow of Lower Deep Water, that includes AABW (van Aken, 2000) and the southward flow of NEADW along Reykjanes Ridge. So the resulting 2.8-3.5 Sv found upward in the Western European Basin includes the upwelling due to the blocking of the Lower Deep Water by the bathymetry, minus the entrainment by the Iceland Scotland Overflow (about $1 \mathrm{~Sv}$ in (Smethie and Fine, 2000)). A net NEADW southward export of 2-4 Sv is found in the DWBC east of the Reykjanes Ridge in June 2002 and 2004, consistently with previous estimates of Saunders (1994).

To conclude this section, the 4-5 Sv increase in the transport over Reykjanes Ridge in June 2004, as compared to 2002, is the most noticeable result of this analysis. We will now show how this result modified the hydrological properties of the northeastern subpolar gyre in the intermediate layer.

\section{Origin and Fate of the Flow across the Reykjanes Ridge}

\subsection{Evolution of the hydrological properties along the subpolar gyre circulation}

In order to better identify the water masses advected from the Iceland Basin to the Irminger Sea, the eastern subpolar gyre is divided into three regions. Each region is illustrated in Figure 10 by two $\theta$-S plots of the corresponding Ovide stations in OV02 and OV04, over color patches indicating the transports binned in the $\theta$-S space.

The first region to be discussed is the Iceland Basin, between the top of Reykjanes Ridge to the northern limit of the NAC. The cyclonic circulation of the Iceland Basin is particularly visible in OV04 (Figure 10b), where the fresher waters are advected northward, in the eastern Iceland Basin and west of the NAC, and the saltier southward, along Reykjanes Ridge. This repartition of transport-properties in the upper layer shows that (i) the origin of the salt along Reykjanes Ridge has to be found more to the north-east in the NAC (Pollard et al., 2004; Thierry et al., 2008), and (ii) the SubArctic Intermediate Water (SAIW) visible by the relative minima in salinity (Harvey and Arhan, 1988) and advected northward in the Iceland Basin has a minor influence near the ridge. The bipolar transport-property repartition is much less clear in 2002 (Figure 10a), because the 

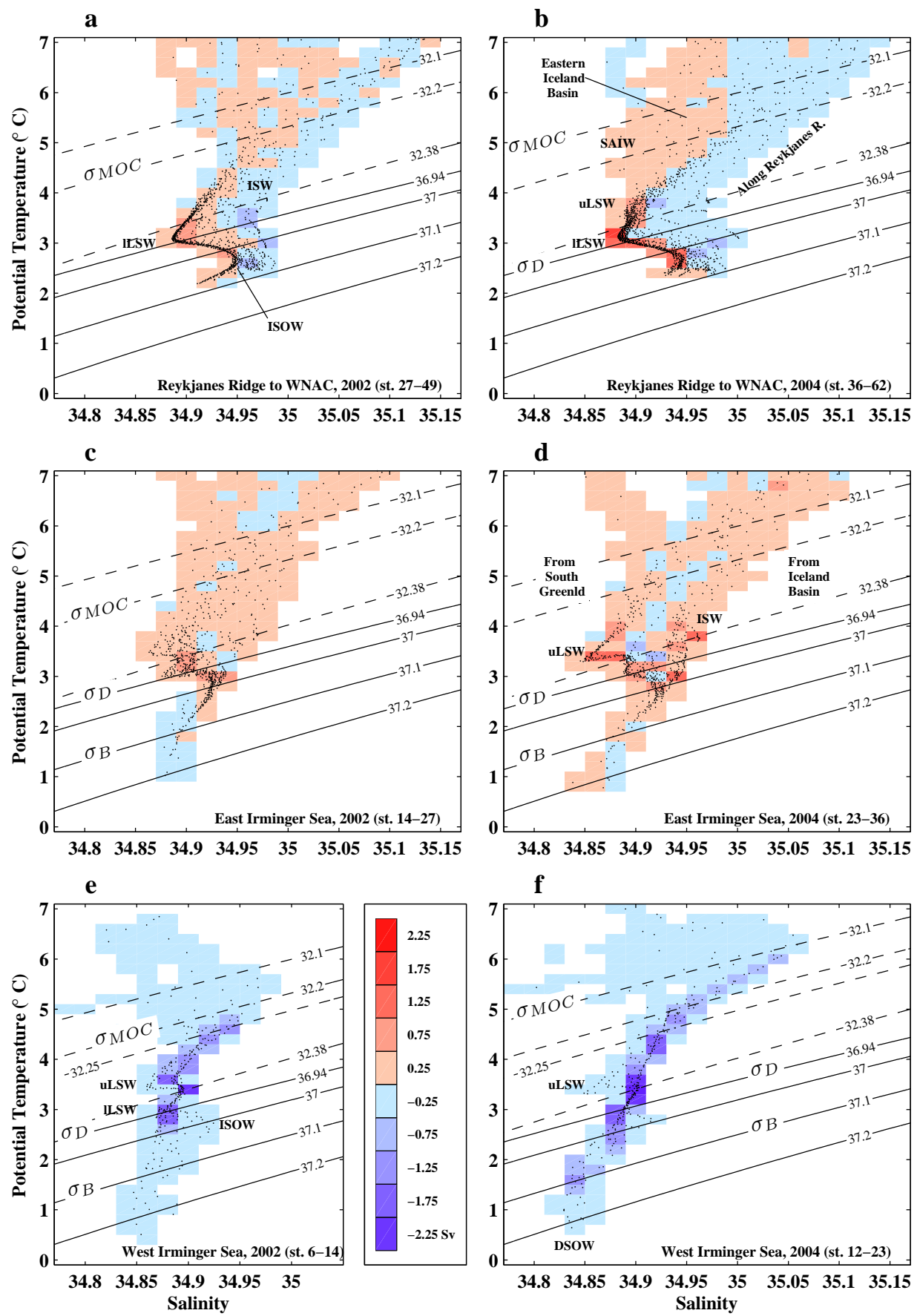

Figure 10: $\theta$-S diagrams in Ovide 2002 (left) and Ovide 2004 (right) in three regions: Iceland Basin (top), East Irminger (middle) and West Irminger (bottom). Stations bounding the regions are detailed in Table 2 and plotted in Figure 1. Properties are plotted with a 50 dbar vertical resolution (black points). Isopycnals are drawn (dashed lines for $\sigma_{1}$ and plain lines for $\sigma_{2}$ ). Transports are shown in color by bins of $0.2^{\circ} \mathrm{C}$ and 0.02 in salinity, positive north-eastward. ISOW: Iceland-Scotland Overflow Water; uLSW and lLSW: upper and lower Labrador Sea Water; SAIW: SubArctic Intermediate Water; ISW: Icelandic Slope Water; DSOW: Denmark Strait Overflow Water. 
cyclonic circulation was quite weak and the SAIW not so present. However, the southward current east of the ridge also transports the saltier water.

The eastern Irminger Sea (Figures 10c and 10d) is subject to the influence of the north-eastward Irminger Current. The origin of this current is still debated. It is generally admitted that the barotropic anticyclonic circulation observed around Reykjanes Ridge during Ovide surveys exists all year round, following $f / H$ contours (Bower et al., 2002; Treguier et al., 2005). In our observations, the Irminger Current has the structure typical of summer as described in Knutsen et al. (2005). Further west, Lavender et al. (2005) describe narrow cyclonic circulations just offshore Greenland that connect the central Labrador Sea and central Irminger Sea, and are mainly winddriven and present all-year long according to Spall and Pickart (2003). Those circulation patterns are represented schematically in Figure 1b. In June 2004 (Figure 10d), one clearly finds the two distinct influences in the upper layer (above about $1700 \mathrm{~m}$ ) advected northward: on the one hand, a relatively salty mixing line proper to the Icelandic Slope Water (ISW), a mixture of ISOW and Atlantic thermocline water described by Yashayaev et al. (2007) and flowing southward on the east side of the ridge (Figure 10a and b); on the other hand, a fresher mixing line that incorporates the upper Labrador Sea Water (uLSW) and most likely belongs to the inner subpolar gyre. So this analysis reveals the dual origin of the Irminger Current (Iceland Basin and south of Greenland). Any significant shortcut of the NAC from the Charlie-Gibbs Fracture Zone, as described by Pollard et al. (2004) in 1996, would have brought much saltier water into the Irminger Sea, and is there- fore very unlikely here.

The western boundary current is characterized by the southward EGIC above $\sigma_{D}$, whose hydrological properties are found to be very different in June 2002 and 2004. The EGIC is usually defined between the coast and the center of the thermal dome near the surface (station 23 in Figure 2a); going eastward from Greenland along the section, it stops where the flow reverses, $200 \mathrm{~km}$ from the coast and on the $2800 \mathrm{~m}$ isobath. Figures $10 \mathrm{e}$ and $10 \mathrm{f}$ show in dark blue which water masses are the most represented in the core of the EGIC. In June 2002 , the water mass signatures are quite well preserved, with fresh elbows characteristic of the uLSW and the lower LSW (lLSW), and the salty influence of the ISOW underneath. By contrast, the June $2004 \theta$ $S$ plot exhibits a nearly straight mixing line from the intermediate water to a quite fresh DSOW ( $\mathrm{S}=34.83$ ) in the core of the current. Only in the offshore rim of the current can the signature of the uLSW be found (on two pairs of stations). The other striking difference between Figures 10e and 10f is the significant southward transport of relatively salty intermediate water in 2004, at densities around $\sigma_{1}=32.15$, just below $\sigma_{M O C}$. A finer analysis of the EGIC indicates a transport of $5.6 \mathrm{~Sv}$ of this water, i.e. $4.3 \mathrm{~Sv}$ more than in June $2002\left(32.1<\sigma_{1}<32.25\right.$, $\mathrm{S}>34.95$, Figure 10f). Water within this isopycnal layer is found between 130 and $370 \mathrm{~m}$, i.e. $100 \mathrm{~m}$ thicker and deeper than in 2002.

\subsection{Origin of the warm and salty anomaly in the EGIC in June 2004}

Based on the previous analysis, we modified the limits of the domain of Figure 10 (that were based on transport arguments) and identified five new regions with coherent 
a) 2002

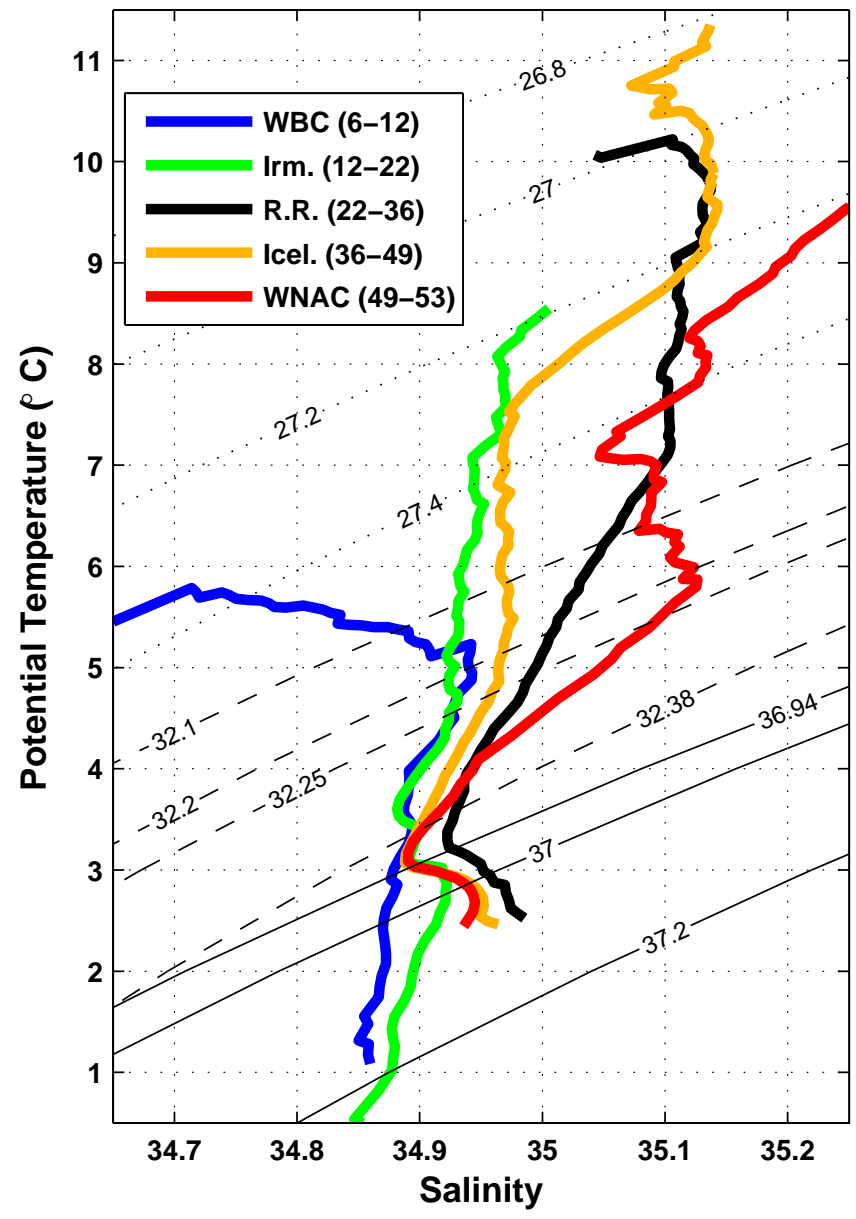

b) 2004

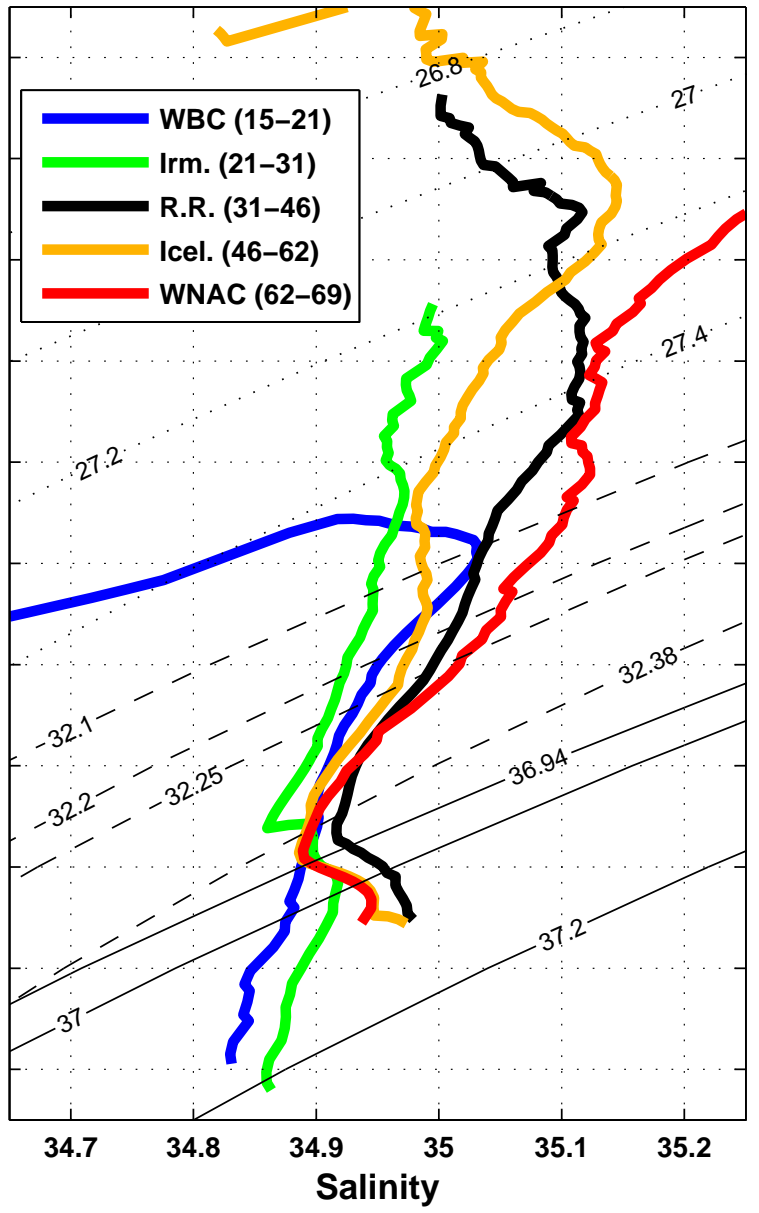

Figure 11: $\theta$-S profiles averaged along isopycnals in the different hydrological realms of the Ovide section northern part, which limits are detailed in Table 2. WBC stands for the core of the western boundary current (from the shelf break to $130 \mathrm{~km}$ from Greenland); Irm.: the central Irminger Sea (delimited by the presence of uLSW); R.R.: the Reykjanes Ridge (delimited by the anticyclonic circulation around it); Icel.: the central Iceland Basin; WNAC: the most western branch of the North Atlantic Current. $\sigma_{0}$ (dotted lines), $\sigma_{1}$ (dashed) and $\sigma_{2}$ (plain) are plotted. 


\begin{tabular}{|l|c|c|}
\hline Region & $\begin{array}{c}2004(2002) \\
\text { stations }\end{array}$ & Location \\
\hline & $\mathbf{1 2}($ none) & $59^{\circ} 52^{\prime} \mathrm{N}, 42^{\circ} 56^{\prime} \mathrm{W}$ \\
WBC & $15(\mathbf{6})$ & $59^{\circ} 50^{\prime} \mathrm{N}, 42^{\circ} 32^{\prime} \mathrm{W}$ \\
- & $\mathbf{2 1}(\mathbf{1 2})$ & $59^{\circ} 45^{\prime} \mathrm{N}, 40^{\circ} 54^{\prime} \mathrm{W}$ \\
Irm. & $\mathbf{2 3}(\mathbf{1 4})$ & $59^{\circ} 41^{\prime} \mathrm{N}, 39^{\circ} 35^{\prime} \mathrm{W}$ \\
- & $\mathbf{3 1}(\mathbf{2 2})$ & $59^{\circ} 10^{\prime} \mathrm{N}, 34^{\circ} 29^{\prime} \mathrm{W}$ \\
R.R. & $\mathbf{3 6}(\mathbf{2 7})$ & $58^{\circ} 51^{\prime} \mathrm{N}, 31^{\circ} 17^{\prime} \mathrm{W}$ \\
Icel. & $\mathbf{4 6}(\mathbf{3 6})$ & $56^{\circ} 37^{\prime} \mathrm{N}, 27^{\circ} 33^{\prime} \mathrm{W}$ \\
- & $\mathbf{6 2}(44)$ & $53^{\circ} 39^{\prime} \mathrm{N}, 25^{\circ} 14^{\prime} \mathrm{W}$ \\
& $68(\mathbf{4 9})$ & $51^{\circ} 46^{\prime} \mathrm{N}, 23^{\circ} 47^{\prime} \mathrm{W}$ \\
WNAC & $\mathbf{6 9}(50)$ & $51^{\circ} 24^{\prime} \mathrm{N}, 23^{\circ} 29^{\prime} \mathrm{W}$ \\
& $72(\mathbf{5 3})$ & $50^{\circ} 17^{\prime} \mathrm{N}, 22^{\circ} 36^{\prime} \mathrm{W}$ \\
& $75(\mathbf{5 6})$ & $49^{\circ} 09^{\prime} \mathrm{N}, 21^{\circ} 44^{\prime} \mathrm{W}$ \\
& $\mathbf{7 9}(60)$ & $47^{\circ} 40^{\prime} \mathrm{N}, 20^{\circ} 33^{\prime} \mathrm{W}$ \\
\hline
\end{tabular}

Table 2: Limits of the hydrological regions plotted in Figure 10 and 11. Station numbers used in the text and the figures are in bold characters. Correspondence between 2002 and 2004 numbering is indicated (2002 numbers are between parenthesis), so that all stations can be located in Figure 1 where 2004 stations are plotted.

hydrological properties in the subpolar gyre (limits detailed in Table 2). The mean properties of waters in those regions are plotted in Figure 11. The WNAC is included, and the outer rim of the EGIC (marked by the presence of uLSW) belongs to the central Irminger Sea. We observe that the mean properties of the WNAC, of the central Iceland Basin and those above Reykjanes Ridge did not change significantly between 2002 and 2004. Noteworthy contrasts are found in the western boundary current, where a warm and salty anomaly between $\sigma_{M O C}$ and 32.25 (up to $6.2^{\circ} \mathrm{C}$ and 35.03 ) in June 2004 has properties very similar to those found on the Reykjanes Ridge, and less than 0.1 fresher than those of the WNAC. A small $\theta-\mathrm{S}$ inflection point is also found in the 2002 western boundary current at $\sigma_{M O C}$ (i.e. $\sigma_{1}=32.2$ in 2002 ), up to $5.2^{\circ} \mathrm{C}$ and 34.94 in Figure 11, but it cannot be so clearly linked to the Irminger Current properties on Reykjanes Ridge. The warm and salty layer of the EGIC is capped by very fresh surface water of polar origin, down to $\sigma_{M O C}(\sim 210 \mathrm{~m}$ in $2002, \sim 130 \mathrm{~m}$ in 2004$)$.

So, the water mass analysis confirms the strongest connection between the WNAC and the EGIC above $\sigma_{1}=32.25$ in June 2004, supporting the 4-5 Sv increase in the circulation of the intermediate layer above the Reykjanes Ridge. The preservation of the hydrological properties under $\sigma_{M O C}$ indicates that this connection was probably fast.

This synthetic $\theta$-S plot also captures the water mass transformation that characterizes the MOC, from warm and salty water $\left(\mathrm{T}>6^{\circ} \mathrm{C}\right.$ and $\left.\mathrm{S}>35.1\right)$ to colder and fresher water $\left(\mathrm{T}<5^{\circ} \mathrm{C}\right.$ and $\left.\mathrm{S} \sim 34.9\right)$.

\section{Discussion and conclusion}

The different components of the North Atlantic circulation were estimated across the Ovide section using an inverse model. On the eastern edge of the North Atlantic subpolar gyre, along the Ovide section, the NAC system was characterized by energetic eddies, among which two main branches, called here the WNAC and the ENAC, were distinguished. While the WNAC was found in the prolongation of the Rockall plateau in June 2002 , it was $200 \mathrm{~km}$ more to the north in June 2004, in the prolongation of the Hatton plateau. Those two distinct positions of the WNAC recall the southern and northern modes described by Bower and von Appen (2008) at the vicinity of Charlie-Gibbs and Faraday Fracture Zones in summer 2002 and 2004 respectively. Most of the $8 \mathrm{~Sv}$ ENAC top layer transport (Figure 8) passed the Iceland-Scotland Sills, while about $8 \mathrm{~Sv}$ 
of the WNAC in the same density layer flowed toward the Irminger Sea where the water densified during the previous winter within the eastern subpolar gyre is evacuated via the EGIC (Brambilla et al., 2008; McCartney and Talley, 1984). Of course, additional datasets and models are required to further study the stability of the consistency between the ENAC and the outflow into the Nordic seas. Furthermore, the strong eddies observed between the two NAC main branches were likely to facilitate significant water mass exchanges.

When measured across the section at $58^{\circ}$ N50', the Irminger Current in OV02 and OV04 is estimated at $12 \pm 3 \mathrm{~Sv}$ northward west of Reykjanes Ridge and balances the southward transport of slightly warmer and saltier water measured on the other flank of the ridge. In the Irminger Sea, the Irminger Current is fed downstream by the transport over Reykjanes Ridge. Building on the (documented) assumption that the transports over the Greenland-Scotland Sills have a small variability at monthly to interannual time scales, we found a $14 \mathrm{~Sv}$ transport over Reykjanes Ridge in June 2004, between the section and Iceland (Figure 9). Compared to June 2002, the additional transport of 4-5 Sv was related to the transport increase in the intermediate layer upstream (Figure 7). No clear increase could be found in the surface currents seen by altimetry, confirming that the anomaly on Reykjanes Ridge is found in a sub-surface density layer. In the year 2001, Pickart et al. (2005) observed no transport increase in the Irminger Current between their estimates at $59^{\circ} \mathrm{N}$ west of Reykjanes Ridge and at $65^{\circ} \mathrm{N}$ off Greenland. This apparent contradiction with a significant flux over Reykjanes Ridge can only be explained by a detrainment of similar amplitude from the Irminger Current as it flows along Reykjanes Ridge. This detrained water would ultimately merge with the western boundary current along its path off Greenland.

At $60^{\circ} \mathrm{N}$, west of the narrow cyclonic circulation mentioned in section 6.1 , the EGIC is found at $23.7 \mathrm{~Sv}$ in OV04, when integrated from the surface to $\sigma_{D}$. Compared to OV02, the $3.2 \mathrm{~Sv}$ net transport increase is concentrated in the upper intermediate layer (Figure 12). Below $\sigma_{D}$, the DWBC transports 11.2 Sv southward, with the $2.1 \mathrm{~Sv}$ increase totally located above the DSOW layer (i.e. above the dashed line in Figure 12). So the 4 to $5 \mathrm{~Sv}$ intensification of the intermediate layer circulation found in the WNAC and over Reykjanes Ridge is observed in the western boundary current over a density range that includes the deep layer, while the import of NEADW in the eastern Irminger Sea has not changed (Figure 12). The large diapycnal diffusivity observed in the western boundary current by Lauderdale et al. (2008) (up to $10^{-3} \mathrm{~m}^{2} \mathrm{~s}^{-1}$ in the EGIC) likely explain this intensified entrainment of intermediate water in the DWBC in OV04, modifying the vertical distribution of transport mainly below $\sigma_{M O C}$ and erasing the hydrographic signatures of the LSW and ISOW (Figure 11).

The bottom layer, representative of the DSOW core, transports $2 \mathrm{~Sv}$ in both years (Figure 7), but is marked by much fresher waters in June 2004. This steadiness is in agreement with Dickson and Brown (1994) conclusion, although it may also be a coincidence considering the monthly variability of the DSOW transport at the Denmark Strait (between 2 and $4 \mathrm{~Sv}$ in Macrander et al. (2005)).

It can be objected that the transports estimated in OV02 and OV04 may result from a daily to weekly variability. However, 


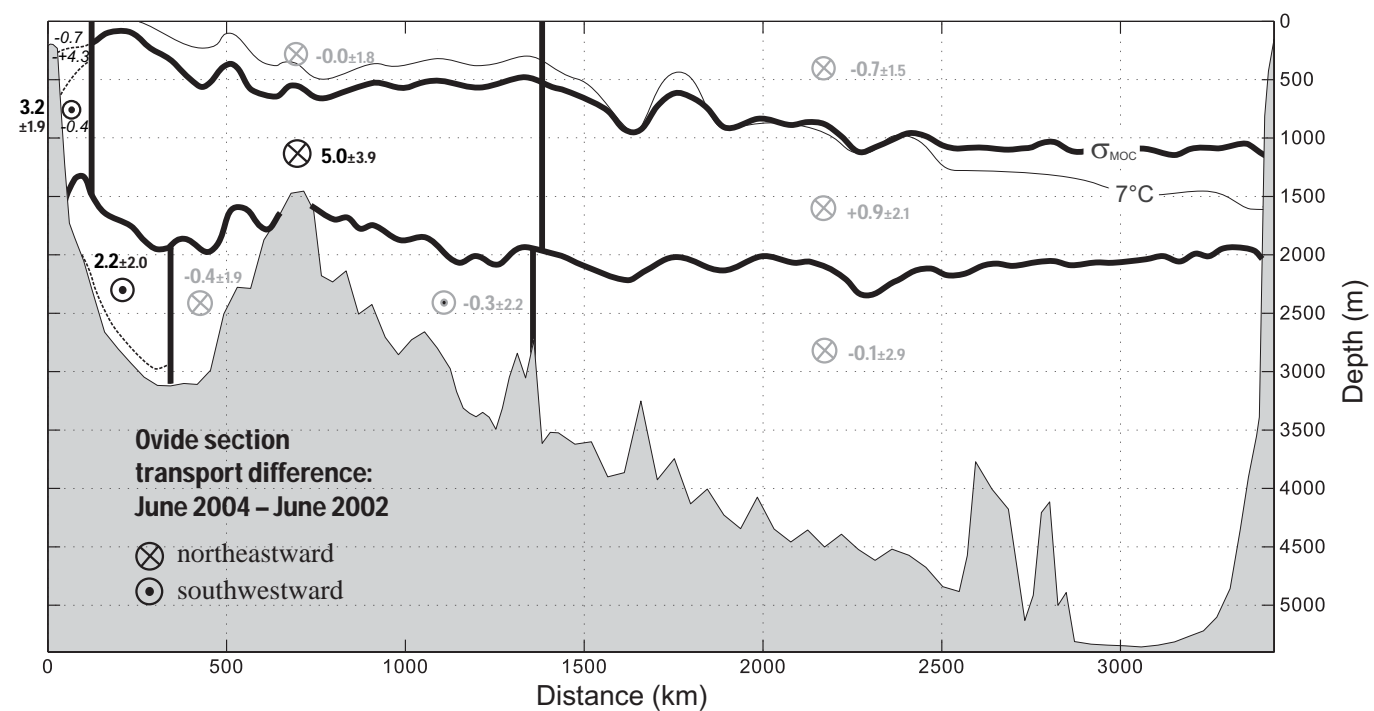

Figure 12: Differences in transports (Sv) across the Ovide section: June 2004 minus June 2002. Grey values are not significant. Direction symbols are plotted according to the usual direction of the flow, and differences are algebraic. Thick lines separing the regions refer to the maximum of the MOC $\left(\sigma_{M O C}\right)$, the upper limit of the deep water $\left(\sigma_{D}\right)$, the eastern limits of the EGIC and of the DWBC, and the northern limit of the NAC. Dotted isopycnal lines in the western boundary current are $\sigma_{M O C}, \sigma_{1}=32.25$ and $\sigma_{B}$.

as shown by Ganachaud (2003) and discussed in Section 2.3.2, most of this high frequency variability is damped by the inversion method that mixes observations made over three weeks. This is confirmed by the first analysis of the EGIC transport made by an array of currentmeters, showing that our results are consistent with one-month averages (Daniault et al., 2010). At longer timescales, realistic models show that the monthly variability of the $\mathrm{MOC}_{\sigma}$ and of the boundary currents is weaker between June and August (A.-M. Treguier, pers. communication).

In June 2004, a noticeable anomaly of warm and salty water was found in the upper intermediate layer $\left(\sigma_{1}=32.1-32.25\right)$, that did not exist in June 2002. Both transports and properties point to the WNAC as its only possible origin. The advection of such an anomaly directly from the NAC into the Irminger Sea (west of the MidAtlantic Ridge) is disregarded here, considering the relatively fresh properties of the eastern Irminger Sea (Figure 10). A focus process study will be needed to elucidate the timescales of the anomalies in transport and properties of the Irminger Current. However, this intrusion of warm and salty water into the subpolar gyre is consistent with our observation of the northwestward shift of the WNAC. At decadal timescales, it also relates with an increasing intrusion of subtropical water in the eastern North Atlantic in the 2000s (Hátún et al., 2005; Johnson and Gruber, 2007; Holliday et al., 2008; Häkkinen and Rhines, 2009).

The $\mathrm{MOC}_{\sigma}$ was found to be the same during OV02 and OV04, at about $16 \mathrm{~Sv}$ (Figure 6), despite the changes in the horizontal circulation of the subpolar gyre intermediate layer. The densification of Atlantic 
Water in the Nordic seas results in $6 \mathrm{~Sv}$ overflows at the Greenland-Scotland ridge seen at the bottom of the DWBC, and we assumed them to be similar in 2002 and 2004. An entrainment of about $2 \mathrm{~Sv}$ is expected to increase the Denmark Strait Overflow transport shortly after the sill (Dickson and Brown, 1994). Some entrainment (less than $2 \mathrm{~Sv}$ ) is also expected downstream the Iceland-Scotland overflow, although the balance with a plausible upwelling across $\sigma_{M O C}$ cannot be quantified here. As a result, about $8 \mathrm{~Sv}$ of the $\mathrm{MOC}_{\sigma}$ are inherently associated with the overflows.

There are still about $8 \mathrm{~Sv}$ to explain in the $\mathrm{MOC}_{\sigma}$ value. According to our results, those find their source in the horizontal circulation formed mainly by the WNAC above $\sigma_{M O C}$ northward and the EGIC below this isopycnal southward. The top of the DWBC ( $3 \mathrm{~Sv}$ in OV04, and $1 \mathrm{~Sv}$ in OV02) is also part of this balance, via the entrainment under the EGIC, and the variability of the intermediate layer circulation modifies the transport distribution in the lower limb of the $\mathrm{MOC}_{\sigma}$ without changing its amplitude. So the $8 \mathrm{~Sv}$ integral transport southward, above the overflow contribution, is mainly driven by the formation of dense water in the North Atlantic subpolar gyre in winter (Brambilla et al., 2008) that is progressively replaced later on by lighter water via the WNAC along the horizontal circulation of the gyre.

One may expect some seasonal variability in the contribution of the horizontal circulation. This is due to the changing stratification in the subsurface Irminger Sea, and additionally to the influence of the wind on the gyre circulation. This seasonal cycle is not addressed by the measurements since the Ovide section is always repeated in June. In a simulation forced by a time-averaged seasonal cycle, Treguier et al. (2006) show a $4 \mathrm{~Sv}$ peak-to-peak seasonal variability in their $\mathrm{MOC}_{\sigma}$ across the Ovide path, with a maximum in Spring and a minimum in Autumn. At the end of the winter, the EGIC mixed layer deepens and gets denser than $\sigma_{M O C}$, while the stratification did not change much at similar densities in the WNAC (i.e. below the main pycnocline), so that the volume increase at the top of the $\mathrm{MOC}_{\sigma}$ lower limb shall indeed induce a stronger $\mathrm{MOC}_{\sigma}$. Some of the $\mathrm{MOC}_{\sigma}$ variability is also due to the gyre circulation variability induced by the wind, stronger in winter, but this point requires a focused study. Finally, as was observed in the hydrological properties of the Ovide section, a large fraction of the LSW formed in the Labrador Sea recirculates into the subpolar gyre before being advected equatorward in the DWBC. So the $\mathrm{MOC}_{\sigma}$ as calculated here accounts for it, but with a lag that is not clear yet and needs to be better understood.

The Ovide section reveals a complex eastern subpolar gyre that can be seen as an imbrication of four cyclonic circulations: a tight cyclonic circulation off Greenland; a larger but closed gyre (in terms of full-depth stream lines) with an eastern frontier at the northeastern limit of the WNAC (Figure 8); a larger gyre up to the ENAC and to the Greenland-Scotland sills, responsible of about half of the water mass transformation in the subpolar North Atlantic according to this analysis; and the large-scale gyre that includes the Nordic seas and accounts for the other half.

\section{8. acknowledgments}

The authors wish to acknowledge the colleagues and ship crews who collected all 
the data discussed in this paper, and Keith Rodgers for his help in the manuscript. The Quikscat gridded wind data were obtained from CERSAT, at IFREMER, Plouzané (France). For this work, Pascale Lherminier and Catherine Kermabon were supported by Ifremer, Herlé Mercier, Thierry Huck and Pascal Morin by CNRS, Claire Gourcuff by Ifremer and CNES, Fiz F. Perez by the European Commission within the 6th Framework Program (EU FP6 CARBOCEAN Integrated Project, Contract no. 511176). Artem Sarafanov and Anastasia Falina were supported by the Russian Ministry of Education and Science under the "World Ocean" Federal Programme (contract 01.420.1.2.0001), the RFBR grant 0805-00858 and the Russian President grant MK-394.2010.5. The Ovide project mainly relies on funds from Ifremer, INSU and LEFE.

\section{A. The four-box model: method and the a priori solution}

To estimate the unknown fluxes across the box interfaces of Figure 9, one might set the two well-known overflows at $3 \mathrm{~Sv}$ towards the lower boxes, use the transports across the Ovide section to prescribe the exchanges with the Atlantic south of the Ovide section, and then solve the system of equations, beginning by the lower boxes. However, it seems more interesting to estimate errors by solving the system with a generalized least squares method, similar to the one applied previously (Mercier, 1986). The standard errors on the Ovide inversion set the errors on the five volume conservation equations. A unique solution is obtained by setting a priori values for the seven unknown fluxes (Jackson, 1979), compatible with the flux values at the time of the cruises, resulting in transport estimates and errors through the interfaces. For that purpose, we use the annual mean with an $a$ priori error that reflects both the sampling uncertainty and the monthly variability, so that the most likely values relative to our two snapshots of June lies within the a priori ranges.

A state-of-the-art review of the North Atlantic-Nordic Sea exchanges was first presented by Hansen and Østerhus (2000). Since then, an intense period of observations within the EC-VEINS (Variability of Exchanges in Northern Seas) and ASOF (Arctic-Subarctic Ocean Fluxes) studies was achieved, more focused on the variability and the fresh water fluxes. No detectable trend was found in the net exchanges across the Greenland-Scotland sills (Dickson et al., $2008 \mathrm{~b}$ ), at least during the main decade of observations from the late 1990s to 2005. The a priori transports across the seven interfaces were chosen based on those observations, and are described in Table $A$. 


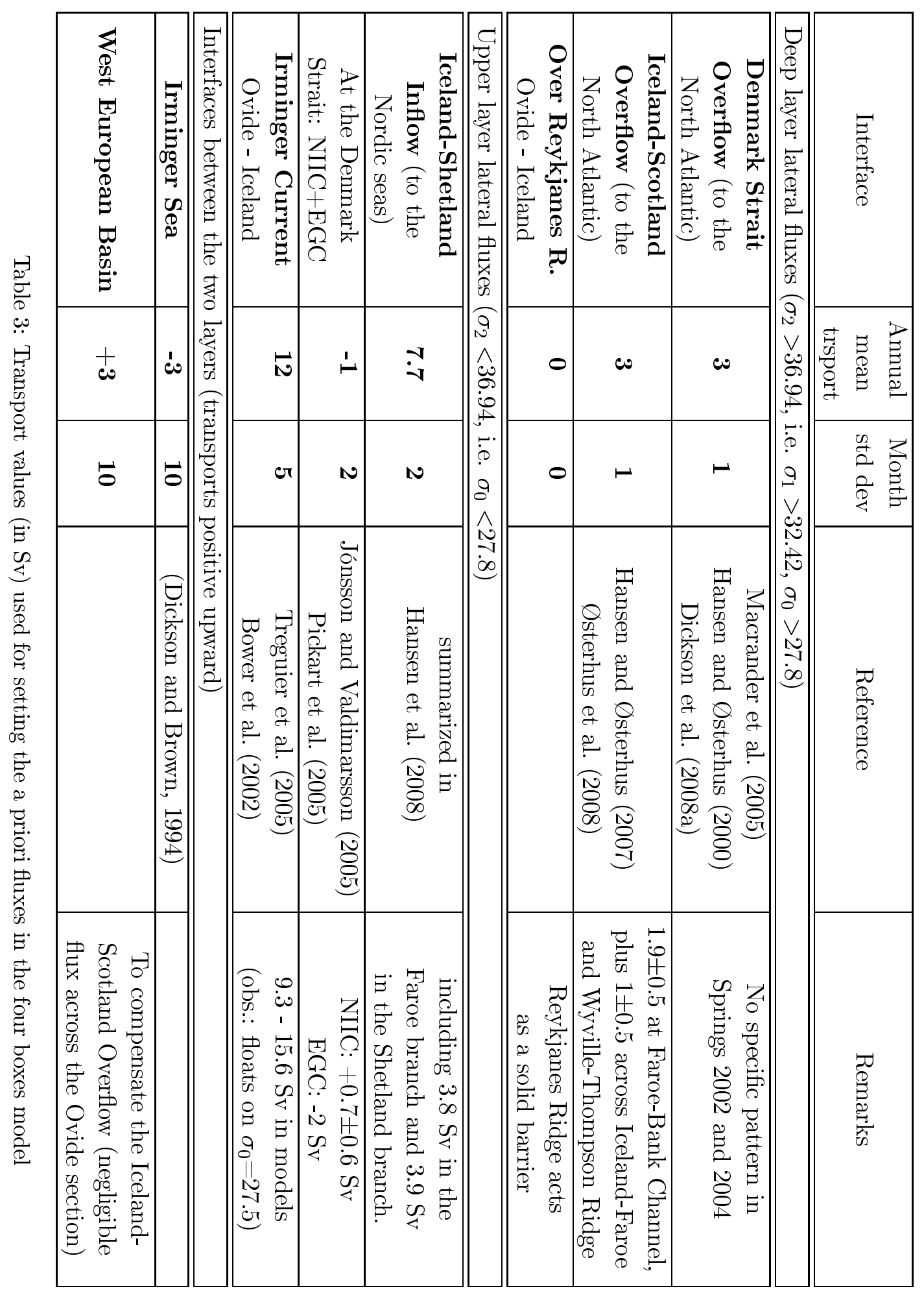




\section{References}

Álvarez, M. F., Bryden, H. L., Pérez, F. F., Ríos, A. F., Roson, G., 2002. Physical and biogeochemical fluxes and net budgets in the subpolar and temperate North Atlantic. J. Mar. Res. 60 (2), 191-226.

Bacon, S., 1998a. Decadal variability in the outflow from the Nordic seas to the deep Atlantic Ocean. Nature 394, 871-874.

Bacon, S., Saunders, P. M., 2010. The deep western boundary current at cape farewell: Results from a moored current meter array. J. Phys. Oceanogr. 40 (4), 815-829.

Belkin, I. M., Levitus, S., 1996. Temporal variability of the Subartic Front near the Charlie-Gibbs Fracture Zone. J. Geophys. Res. 101, 28,87128,874 .

Bersch, M., Meincke, J., Sy, A., 1999. Interannuel thermohaline changes in the northern North Atlantic 1991-1996. Deep-Sea Res. II 46, 55-75.

Biastoch, A., Völker, C., Böning, C. W., 2007. Uptake and spreading of anthropogenic trace gases in an eddy-permitting model of the Atlantic Ocean. J. Geophys. Res. 112 (C09017).

Billant, A., Branellec, P., Huck, T., 2006. Campagne OVIDE 2004: rapport de données CTD$\mathrm{O}_{2}$. Tech. Rep. DRO/DOPS/LPO/06-01, Ifremer.

Bower, A. S., Le Cann, B., Rossby, T., Zenk, W., Gould, J., Speer, K. G., Richardson, P. L., Prater, M. D., Zhang, H.-M., 2002. Directly measured mid-depth circulation in the northeastern North Atlantic Ocean. Nature 419, 603-607.

Bower, A. S., von Appen, W.-J., 2008. Interannual Variability in the Pathways of the North Atlantic Current over the Mid-Atlantic Ridge and the Impact of the Topography. J. Phys. Oceanogr. 38, 104-120.

Brambilla, E., Talley, L. D., Robbins, P. E., 2008. Subpolar Mode Water in the northeastern Atlantic: 2. Origin and transformation. J. Geophys. Res. 113 (C04026).

Cuny, J., Rhines, P. B., Kwok, R., 2005. Davis Strait volume, freshwater and heat fluxes. Deep Sea Res. I 52, 519-542.

Curry, R. G., McCartney, M. S., 2001. Ocean gyre circulation changes associated with the North Atlantic Oscillation. J. Phys. Oceanogr. 31, 3374-3400.

Daniault, N., Lherminier, P., Mercier, H., 2010.
Circulation and transport at the south east tip of greenland. J. Phys. Oceanogr. Subm.

Dickson, R. R., Brown, J., 1994. The production of North Atlantic Deep Water: sources, rates, and pathways. J. Geophys. Res. 99 (C6), 1231912341.

Dickson, R. R., Dye, S., Jonsson, S., Köhl, A., Macrander, A., Marnela, M., Meincke, J., Olsen, S. M., Rudels, B., Valdimarsson, H., Voet, G., 2008a. The overflow flux west of Iceland: Variability, origins and forcing. In: Arctic-Subarctic Ocean Fluxes: Defining the Role of the Northern Seas in Climate. Robert R. Dickson, Jens Meinke and Peter Rhines (eds.) Springer Science + Business Media B. V., P.O. Box 17, 3300 AA Dordrecht, The Netherlands, pp. 427-440.

Dickson, R. R., Meincke, J., Rhines, P. (Eds.), 2008b. Arctic-Subarctic Ocean Fluxes: Defining the Role of the Northern Seas in Climate. Springer Science + Business Media B. V., P.O. Box 17, 3300 AA Dordrecht, The Netherlands.

Dittmar, T., Kattner, G., 2003. The biogeochemistry of the river and shelf ecosystem of the Arctic Ocean: a review. Marine Chemistry 83 (3-4), 103-120.

Egbert, G., Bennett, A., Foreman, M., 1994. TOPEX/Poseidon tides estimated using a global inverse model. J. Geophys. Res. 99 (C12), 2482124852 .

Fanning, K., Pilson, M., 1973. On the spectrophotometric determination of dissolved silica in natural waters. Analyt. Chem. 45, 136-140.

Flatau, M. K., Talley, L. D., Niiler, P. P., 2003. The North Atlantic Oscillation, surface current velocities, and SST changes in the Subpolar North Atlantic. J. Climate 16, 2355-2369.

Fogelqvist, E., Blindheim, J., Tanhua, T., Østerhus, S., Buch, E., Rey, F., 2003. GreenlandScotland overflow studied by hydro-chemical multivariate analysis. Deep Sea Res. I 50 (1), 73102.

Ganachaud, A., 2003. Error budget of inverse box models: the North Atlantic. J. Atmos. Ocean. Technol. 20 (11), 1641-1655.

Häkkinen, S., Rhines, P. B., 2004. Decline of subpolar North Atlantic. Science 304, 555-559.

Häkkinen, S., Rhines, P. B., 2009. Shifting surface currents in the northern North Atlantic. J. Geophys. Res. 114 (C04005).

Hansen, B., Østerhus, S., 2000. North AtlanticNordic Seas exchanges. Prog. Ocean. 45, 109- 
208.

Hansen, B., Østerhus, S., 2007. Faroe Bank Channel overflow 1995-2005. Progr. Ocean. 75, 817856.

Hansen, B., Østerhus, S., Turrell, W. R., Jonsson, S., Valdimarsson, H., Hátún, H., Olsen, S. M., 2008. The inflow of Atlantic water, heat, and salt to the nordic seas across the Greenland-Scotland ridge. In: Arctic-Subarctic Ocean Fluxes: Defining the Role of the Northern Seas in Climate. Robert R. Dickson, Jens Meincke and Peter Rhines (eds.) Springer Science + Business Media B. V., pp. 15-43.

Harvey, J. G., Arhan, M., 1988. The water masses of the central North Atlantic in 1983-1984. J. Phys. Oceanogr. 18 (12), 1855-1875.

Hátún, H., Sandø, A. B., Drange, H., Hansen, B., Valdimarsson, H., 2005. Influence of the Atlantic Subpolar Gyre on the Thermohaline Circulation . Science 309, 1841-1844.

Holliday, N. P., Hughes, S. L., Bacon, S., Beszczynska-Möller, A., Hansen, B., Lavin, A., Loeng, H., Mork, K. A., Østerhus, S., Sherwin, T., Walczowski, W., 2008. Reversal of the 1960s to 1990s freshening trend in the northeast North Atlantic and Nordic Seas. Geophys. Res. Lett. 35 (L03614).

Huck, T., de Verdière, A. C., Estrade, P., Schopp, R., 2008. Low-frequency variations of the largescale ocean circulation and heat transport in the North Atlantic from 1955-1998 in situ temperature and salinity data. Geophys. Res. Lett. 35 (L23613).

Jackson, D. D., 1979. The use of a priori data to resolve non-uniqueness in linear inversion. Geophys. J. R. Astron. Soc. 57, 137-157.

Johnson, G. C., Gruber, N., 2007. Decadal water mass variations along $20^{\circ} \mathrm{W}$ in the Northeastern Atlantic Ocean. Prog. Oceanogr. 73, 277-295.

Jónsson, S., Valdimarsson, H., 2005. The flow of Atlantic water to the North Icelandic Shelf and its relation to the drift of cod larvae. ICES J. Mar. Sci. 62, 1350-1359.

Joyce, T. M., 1991. WOCE Operations Manual: WHP Operations and Methods. Tech. Rep. WOCE Report no 68/91, Woods Hole Ocean. Inst.

Knutsen, Ø., Svendsen, H., Østerhus, S., Rossby, T., Hansen, B., 2005. Direct measurements of the mean flow and eddy kinetic energy structure of the upper ocean circulation in the NE Atlantic.
Geophys. Res. Lett. 32 (L14604).

Lauderdale, J. M., Bacon, S., Garabato, A. C. N., Holliday, N. P., 2008. Intensified turbulent mixing in the boundary current system of southern Greenland. Geophys. Res. Lett. 35 (L04611).

Lavender, K. L., Owens, W. B., Davis, R. E., 2005. The mid-depth circulation of the subpolar North Atlantic Ocean as measured by subsurface floats. Deep Sea Res. I 52, 767-785.

Lherminier, P., Mercier, H., Gourcuff, C., Álvarez, M. F., Bacon, S., Kermabon, C., 2007. Transport across the 2002 Greenland-Portugal section and comparison with 1997. J. Geophys. Res. 112 (C07003).

Lux, M., Mercier, H., Arhan, M., 2000. Interhemispheric exchanges of mass and heat in the Atlantic Ocean in January-March 1993. Deep Sea Res. I 48, 605-638.

Macrander, A., Send, U., Valdimarsson, H., Jonsson, S., Käse, R. H., 2005. Interannual changes in the overflows from the Nordic Seas into the Atlantic Ocean through Denmark Strait. Geophys. Res. Lett. 32 (L06606).

Marsh, R., de Cuevas, B. A., Coward, A. C., Bryden, H. L., Álvarez, M. F., 2005. Thermohaline circulation at three key sections in the North Atlantic over 1985-2002. Geophys. Res. Lett. 32 (L10604).

Maslowski, W., Marble, D., Walczowski, W., Schauer, U., Clement, J. L., Semtner, A. J., 2004. On climatological mass, heat and salt transports through the Barents Sea and Fram Strait from a pan-Arctic coupled ice-ocean model simulation. J. Geophys. Res. 109 (C3), C03032.

McCartney, M. S., 1992. Recirculating components to the deep boundary current of the northern North Atlantic. Prog. Oceanogr. 29 (4), 283-383.

McCartney, M. S., Talley, L. D., 1984. Warm-tocold water conversion in the northern North Atlantic. J. Phys. Oceanogr. 12, 1169-1188.

Mercier, H., 1986. Determining the General Circulation of the Ocean: A Non Linear Inverse Problem. J. Geophys. Res. 91 (C4), 5103-5109.

Østerhus, S., Shervin, T., Quadfasel, D., Hansen, B., 2008. The Overflow Transport East of Iceland. In: Arctic-Subarctic Ocean Fluxes: Defining the Role of the Northern Seas in Climate. Robert R. Dickson, Jens Meincke and Peter Rhines (eds.) Springer Science + Business Media B. V., pp. 427-440.

Østerhus, S., Turrell, W. R., Jonsson, S., Hansen, 
B., 2005. Measured volume, heat and salt fluxes from the Atlantic to the Arctic Mediterranean. Geophys. Res. Lett. 32 (L7603).

Paillet, J., Mercier, H., 1997. An inverse model of the eastern North Atlantic general circulation and thermocline ventilation. Deep Sea Res. I 44 (8), 1293-1328.

Pérez, F. F., Vázquez-Rodríguez, M., Louarn, E., Padín, X. A., Mercier, H., Ríos, A. F., 2008. Temporal variability of the anthropogenic $\mathrm{CO}_{2}$ storage in the irminger sea. Biogeosciences 5 , 1669-1679.

Pickart, R. S., Torres, D. J., Fratantoni, P. S., 2005. The East Greenland Spill Jet. J. Phys. Oceanogr. 35, 1037-1053.

Pollard, R. T., Read, J. F., Holliday, N. P., 2004. Water masses and circulation pathways through the Iceland Bassin during Vivaldi 1996. J. Geophys. Res. 109 (C04004).

Price, J. F., Baringer, O., 1994. Outflows and deep water production by marginal seas. Prog. Oceanogr. 33, 161-200.

Sarafanov, A., 2009. On the effect of the North Atlantic Oscillation on temperature and salinity of the subpolar North Atlantic intermediate and deep waters. ICES J. Mar. Sci. 66, 1448-1454.

Sarafanov, A., Falina, A., Lherminier, P., Mercier, H., Sokov, A., Gourcuff, C., 2010a. Assessing decadal changes in the Deep Western Boundary Current absolute transport southeast of Cape Farewell (Greenland) from hydrography and altimetry. J. Geophys. Res. 115 (doi:10.1029/2009JC005811).

Sarafanov, A., Falina, A., Mercier, H., Lherminier, P., Sokov, A., 2009. Recent changes in the Greenland-Scotland overflow-derived water transport inferred from hydrographic observations in the southern Irminger Sea. Geophys. Res. Lett. 36 (L13606).

Sarafanov, A., Falina, A., Sokov, A., Demidov, A., 2008. Intense warming and salinification of intermediate waters of southern origin in the eastern subpolar North Atlantic in the 1990s to mid2000s. J. Geophys. Res. 113 (C12022).

Sarafanov, A., Mercier, H., Falina, A., Sokov, A., Lherminier, P., 2010b. Cessation and partial reversal of deep water freshening in the northern North Atlantic: observation-based estimates and attribution. Tellus A 62A, 80-90.

Saunders, P. M., 1987. Flow through Discovery Gap. J. Phys. Oceanogr. 17, 631-643.
Saunders, P. M., 1994. The flux of overflow water through the Charlie Gibbs Fracture Zone. J. Geophys. Res. 99, 12343-12355.

Schott, F., Brandt, P., 2007. Circulation and Deep Water Export of the Subpolar North Atlantic During the 1990's. In: Ocean Circulation, mechanisms and impacts. No. 173 in Geophysical Monograph. AGU, pp. 91-118.

Schott, F., Stramma, L., Fischer, J., 1999. Interaction of the North Atlantic Current with the deep Charlie Gibbs Fracture Zone throughflow. Geophys. Res. Lett. 26, 369-372.

Schott, F., Zantopp, R., Stramma, L., Dengler, M., Fischer, J., Wibaux, M., 2004. Circulation and Deep-Water Export at the Western Exit of the Subpolar North Atlantic. J. Phys. Oceanogr. 34, 817-843.

Serreze, M. C., Barrett, A. P., Slater, A. G., Woodgate, R. A., Aagaard, K., Lammers, R. B., Steele, M., Moritz, R., Meredith, M., Lee, C. M., 2006. The large-scale freshwater cycle of the Arctic. J. Geophys. Res. 111 (C11010).

Smethie, William M., J., Fine, R. A., 2000. Rates of North Atlantic Deep Water formation calculated from chlorofluorocarbon inventories. Deep Sea Res. I 48 (1), 189-215.

Spall, M. A., Pickart, R. S., 2003. Wind-driven recirculations and exchange in the Labrador and Irminger seas. J. Phys. Oceanogr. 33 (8), 18291845 .

Thierry, V., de Boisseson, E., Mercier, H., 2008. Interannual variability of Subpolar Mode Water properties over the Reykjanes Ridge during 19902006. J. Geophys. Res. 113 (C04016).

Treguier, A.-M., Gourcuff, C., Lherminier, P., Mercier, H., Barnier, B., Madec, G., Molines, J.-M., Penduff, T., Czeschel, L., Böning, C. W., 2006. Internal and forced variability along a section between Greenland and Portugal in the CLIPPER Atlantic model. Oceans Dyn. 56, 568580.

Treguier, A.-M., Theetten, S., Chassignet, E. P., Penduff, T., Smith, R., Talley, L. D., Beismann, J. O., Böning, C. W., 2005. The North Atlantic subpolar gyre in four high-resolution models. J. Phys. Oceanogr. 35 (5), 757-774.

van Aken, H. M., 2000. The hydrography of the mid-latitude Northeast Atlantic Ocean: II: The intermediate water masses. Deep Sea Res. I 47 (5), 789-824.

Visbeck, M., 2002. Deep velocity profiling us- 
ing Lowered Acoustic Doppler Current Profilers: bottom track and inverse solutions. J. Atmos. Ocean. Technol. 19 (5), 794-807.

Yashayaev, I., Bersch, M., van Aken, H. M., 2007. Spreading of the Labrador Sea Water to the Irminger and Iceland basins. Geophys. Res. Lett. 34 (L10602).

Yashayaev, I., Dickson, R. R., 2008. Transformation and fate of overflows in the northern North Atlantic. In: Arctic-Subarctic Ocean Fluxes: Defining the Role of the Northern Seas in Climate. Robert R. Dickson, Jens Meinke and Peter Rhines (eds.) Springer Science + Business Media B. V., P.O. Box 17, 3300 AA Dordrecht, The Netherlands, pp. 505-526. 